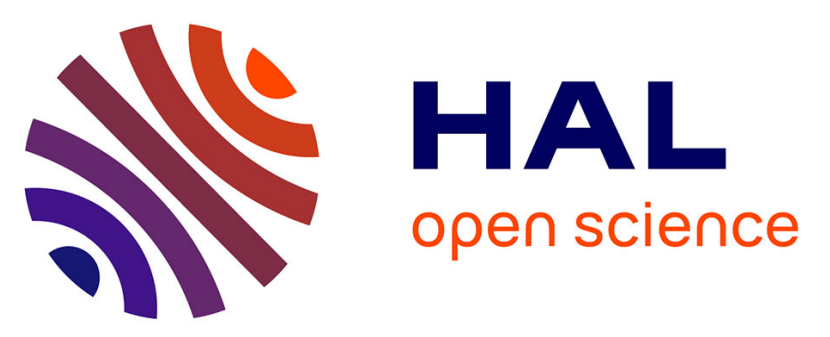

\title{
Distribution of Asian knotweeds on the Rhône River basin, France: A multi-scale model of invasibility that combines biophysical and anthropogenic factors
}

\author{
O. Navratil, N Brekenfeld, Sara Puijalon, M Sabastia, M Boyer, H Pella, J
} Lejot, Florence Piola

\section{To cite this version:}

O. Navratil, N Brekenfeld, Sara Puijalon, M Sabastia, M Boyer, et al.. Distribution of Asian knotweeds on the Rhône River basin, France: A multi-scale model of invasibility that combines biophysical and anthropogenic factors. Science of the Total Environment, 2021, 763, pp.142995. 10.1016/j.scitotenv.2020.142995 . hal-03024555

\section{HAL Id: hal-03024555 https://hal.science/hal-03024555}

Submitted on 31 Aug 2021

HAL is a multi-disciplinary open access archive for the deposit and dissemination of scientific research documents, whether they are published or not. The documents may come from teaching and research institutions in France or abroad, or from public or private research centers.
L'archive ouverte pluridisciplinaire HAL, est destinée au dépôt et à la diffusion de documents scientifiques de niveau recherche, publiés ou non, émanant des établissements d'enseignement et de recherche français ou étrangers, des laboratoires publics ou privés. 


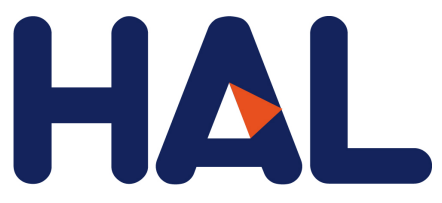

archives-ouvertes

\section{Distribution of Asian knotweeds on the Rhône River basin, France: A multi-scale model of invasibility that combines biophysical and anthropogenic factors}

O. Navratil, N Brekenfeld, S Puijalon, M Sabastia, M Boyer, H Pella, J Lejot, F Piola

\section{To cite this version:}

O. Navratil, N Brekenfeld, S Puijalon, M Sabastia, M Boyer, et al.. Distribution of Asian knotweeds on the Rhône River basin, France: A multi-scale model of invasibility that combines biophysical and anthropogenic factors. Science of the Total Environment, Elsevier, 2020, 10.1016/j.scitotenv.2020.142995 . hal-03024555

\section{HAL Id: hal-03024555 \\ https://hal.archives-ouvertes.fr/hal-03024555}

Submitted on 25 Nov 2020

HAL is a multi-disciplinary open access archive for the deposit and dissemination of scientific research documents, whether they are published or not. The documents may come from teaching and research institutions in France or abroad, or from public or private research centers.
L'archive ouverte pluridisciplinaire HAL, est destinée au dépôt et à la diffusion de documents scientifiques de niveau recherche, publiés ou non, émanant des établissements d'enseignement et de recherche français ou étrangers, des laboratoires publics ou privés. 


\title{
Distribution of Asian knotweeds on the Rhône River basin, France: A multi-scale model of invasibility that combines biophysical and anthropogenic factors.
}

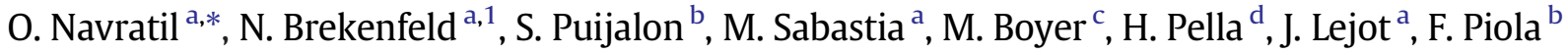 \\ a Univ Lyon, Université Lumière Lyon 2, CNRS, UMR 5600 EVS, F-69635, France

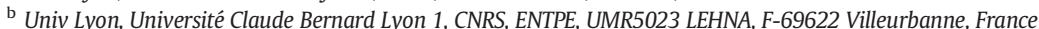 \\ c Concept Cours D'eau, 427 voie Thomas Edison, 73800 Saint Hélène du Lac, France \\ d INRAE, Centre de Lyon-Grenoble Auvergne-Rhône-Alpes, 5 rue de la Doua, CS 2024469625 Villeurbanne Cedex, France
}

\section{H I G H L I G H T S}

- Biotic and abiotic factors control plant introduction, dispersal and establishment in fluvial corridors.

- A multiscale analysis was implemented to explain knotweed occurrence in river basins $\left(<600 \mathrm{~km}^{2}\right)$.

- Knotweed implantation on riverbanks depends on water availability and interspecific competitions.

- River connectivity and hydrogeomorphic forces play major roles in propagule dispersal.

- Consistent knotweed management policies along rivers, roads, and railways are a key issue.

\section{A R T I C L E I N F O}

\section{Article history:}

Received 13 May 2020

Received in revised form 1 October 2020

Accepted 7 October 2020

Available online xxxx

Editor: Sergi Sabater

\section{Keywords:}

Invasive plant

Fallopia spp.

Hydrological regime

Legacy infrastructures

Geomorphic connectivity

Plant-human interactions
G R A P H I C A L A B S T R A C T

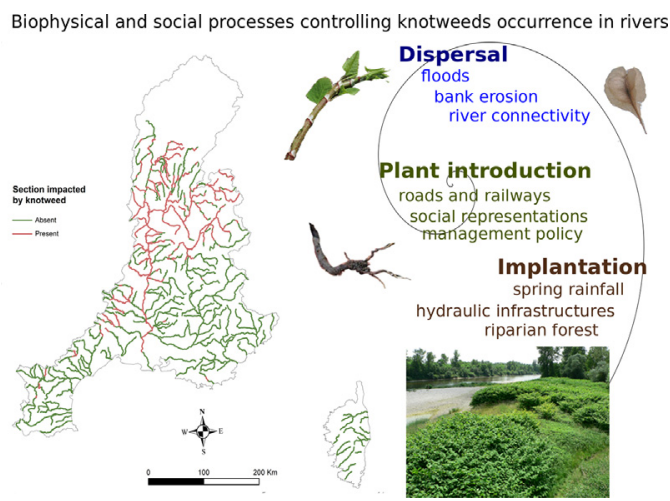

\begin{abstract}
A B S T R A C T
Biotic and abiotic factors are important drivers of the introduction, dispersal and establishment of an invasive species in fluvial corridors. In this study, we propose to better understand the spatial distribution of Asian knotweeds and to model their invasibility at the river basin scale in the Rhône Mediterranean and Corsica regions, France. We implemented a multiscale analysis of biophysical and anthropogenic factors related to the presence of knotweeds. Subbasins were sampled $\left(50-600 \mathrm{~km}^{2}\right)$, a large dataset on knotweed occurrence and biotic/abiotic factors was collected, and logistic regression was applied. A robust logit model (accuracy: 90\%; false positive rate: $13 \%$ ) estimated the probability of the occurrence of knotweeds at the river basin scale. We found clear evidence of: i) spatial scale-dependent water availability for knotweed implantation (e.g., summer vs. winter rainfalls $>250 \mathrm{~mm}$ ); ii) an important role of hydrogeomorphic forces in dispersal; and iii) interspecific competition in riparian areas. The occurrence of knotweeds is also closely related to human-derived pressures. The management of knotweeds on roads and railways in the vicinity of rivers may be a major source of propagules. Hydraulic infrastructures (dikes and mill weirs) may also have served as locations of knotweed introduction since the end of the nineteenth century and may play a major role in the propagule transfer of knotweed; to date, these infrastructures have provided favourable conditions for knotweed establishment. Despite local water authorities' increasing awareness of invasive plants, local management practices for flood mitigation, low awareness of roads/
\end{abstract}

\footnotetext{
* Corresponding author at: Laboratoire Environnement Ville Société UMR-CNRS 5600, University of Lyon2, School of Environment and Society - Study of the Human Past, 5 av. P. Mendès France, bâtiment Europe, 69676 Bron cedex, France.

E-mail address: oldrich.navratil@univ-lyon2.fr (O. Navratil).

1 Present address: School of Geography, Earth and Environmental Sciences, University of Birmingham B15 2TT, Birmingham, UK.
} 
railway managers, and negative representations of knotweeds have probably largely contributed to their dispersion over decades. The final model intends to integrate these biophysical and human factors by providing an operational tool to help river managers determine the sensitivity of their river basins to knotweed invasion.

\section{Introduction}

Many terrestrial invasive plants benefit from following watercourses to extend their range (Catford and Jansson, 2014). Hydrological and hydrogeomorphic processes are considered effective agents for the dispersion and colonization (establishment) of species (Tickner et al., 2001; Boedeltje et al., 2004; Gurnell, 2007). Water exposure favours seed germination and early seedling survival for species sensitive to dry conditions (Funkenberg et al., 2012). Fragmentation of plants by bank erosion during floods can introduce propagules (i.e., stem or rhizome fragments) into the river flow (Truscott et al., 2006), which in turn might favour the dispersal of the plant downstream (i.e., hydrochory; Boedeltje et al., 2003). The mobilization and transfer of propagules by river flows are highly variable in space and time. Indeed, the efficiency of plant transfer is highly associated with the level of hydraulic and geomorphic connectivity of each geomorphic system component (Wohl et al., 2019). The efficiency thus depends on the flood regime, the river morphology and the river slope (Cousens et al., 2008). For instance, river channel enlargement, as well as dense riverine vegetation, create local hydraulic conditions (i.e., low water levels and low velocities), facilitating the accumulation of propagules in specific areas (Schneider and Sharitz, 1988; Mahoney and Rood, 1998; Merritt and Wohl, 2002, 2006; Riis and Sand-Jensen, 2006; Gurnell, 2007). Sediment deposits and erosion processes provide new habitats, e.g., eroded banks, marginal benches and bars and mid-channel bars (Tickner et al., 2001). The hydrological regime is also considered to be a key factor that drives young seedling installation and water/nutrient availability (Mahoney and Rood, 1998). For instance, floods connect different geomorphic units and allow the transfer of seeds and propagules from the main channel to adjacent flood-prone areas where they can find water, light and nutrient resources and lower competition among the dominant species. These hydrological and hydrogeomorphological processes are heavily and widely influenced by human activities (e.g., river dredging, dams and weirs, river eutrophication). Such activities play an essential role in invasive plant dispersal by first facilitating their introduction into the river corridor and increasing the susceptibility of the riverine environment to invasion (Rejmanek, 1989; D'Antonio et al., 1999). For instance, river training and riparian vegetation management plans, such as bank clearing for flood mitigation and river restoration actions, can introduce, remobilize, and facilitate plant invasions in rivers and alluvial margins (Alexander et al., 2011; Catford and Jansson, 2014). Invasive plants thus pose major environmental management issues (Head, 2017). Policy makers, local stakeholders, and scientists' representations of invasive plants strongly effect their perceptions (Cottet et al., 2018). For instance, informal practices of riverbank clearing depend on the local knowledge about the invasive plant. New funding, communication plans and scientific concepts shape the attitudes and practices adopted by local stakeholders in the field. These daily practices shape the biophysical characteristics of riverbanks and the conditions of the introduction, transfer and fate of invasive plants in ecosystems. Thus, in the long term, social representations are strongly influenced by attitudes and practices in the field. The human role and social processes are essential in understanding the processes of plant invasion in riparian ecosystems (Head, 2017) and cannot be disentangled from biophysical processes.

Among plants found on riverbanks, the Fallopia complex (referred to hereafter as knotweeds) is one of the most invasive taxa in the world (Lowe et al., 2000) and intensively colonizes riverbanks (Bailey et al., 2009; Colleran and Goodall, 2014). Negative impacts, including security, biodiversity and landscape issues, are reported in the literature (Lavoie, 2019). However, significant gaps in knowledge have also been identified regarding the effects of knotweeds on biodiversity and ecological processes (Lavoie, 2017). The Fallopia complex includes F. japonica, $F$. sachalinensis, and the complex of polyploid F. $\times$ bohemica hybrids, which originated from the hybridization of $F$. japonica and F. sachalinensis, backcrosses and F2 (Bailey and Conolly, 1985; Bailey et al., 2009). Very popular among horticulturists and botanical gardens during the end of the nineteenth century, knotweeds were distributed as a result of human exchanges and trade throughout France and quickly spread to different places (F. Piola, unpublished data). Then, after these primary introductions, knotweeds progressively colonize terrestrial and aquatic environments. Although the spread of knotweeds has been mainly considered clonal, sexual spread has also been witnessed in Europe (Engler et al., 2011; Rouifed et al., 2011; Buhk and Thielsch, 2015). Sexual propagules consist of a single-seeded achene that is surrounded by a winged fruiting perianth. Achenes of the complex are dispersed through watercourses (Rouifed et al., 2011; LambertiRaverot et al., 2017; Lamberti-Raverot et al., 2019). Vegetative propagules (i.e., fragments of rhizome and aerial stems) also seem to be involved in spreading the complex along watercourses (Mandák et al., 2004; Bailey et al., 2009; Colleran and Goodall, 2014). The establishment of knotweeds on riverbanks also largely depends on river characteristics; i.e., abiotic factors as well as biotic characteristics and human activities (e.g., Bímová et al., 2004; Dommanget et al., 2019). Knotweeds thus represent a very interesting model by which to better understand the interconnected physical, biotic and social processes that unfold in riparian zones.

Examinations of the Rhône River (France) indicate that knotweeds have spread all over the basin within the past decades. In extreme cases, the river reaches show monospecific populations. Many patches have developed on riverbanks and represent important sources of vegetative propagules and achenes that could potentially colonize downstream locations. In contrast, many other river reaches show an astonishingly low level of knotweed invasion despite their presence in subcatchments. Such field observations led us to hypothesize that abiotic and biotic factors at the river basin scale could act as environmental filters, playing a major role in encouraging or limiting the installation and growth of knotweeds along rivers (Bendix and Hupp, 2000).

This study aims to explore the theory of invasibility introduced by Lonsdale (1999), Tilman (1997) and Davis et al. (2000) by identifying the key explanatory variables (e.g., physiographic, climatic, hydrological, hydrogeomorphological, and anthropogenic factors) that could explain the presence or absence of Asian knotweeds in the Rhône River basin. In the words of Lonsdale (1999), to ask whether a river basin is more "invasible" than another is clearly to ask not simply whether it has more exotic species but whether it is intrinsically more susceptible to invasion. To that end, we used a dataset showing the presence/ absence of knotweeds and a large dataset of biophysical and anthropogenic explanatory variables collected over a large territory, ca. $138,500 \mathrm{~km}^{2}$. However, one especially challenging issue in landscape ecology, and in studies of fluvial environments in particular, is the choice of the most relevant spatial scale at which ecological processes are to be considered and at which biogeomorphic relationships are observed (Levin, 1992; Chave, 2013; Bendix and Stella, 2013). Indeed, perceptions of the importance of different ecological processes may vary in a manner that depends on scale (Hewitt et al., 2017); an explanatory variable can have a strong influence on knotweed density at a small 
basin scale (e.g., headwater streams) and much less or even no influence at a larger scale. As the emergence of biogeographic patterns can be scale-dependent (Steinbauer et al., 2016), here, we considered different spatial scales: i) the regional scale, i.e., hydro-ecoregion scale (from 350 to $33,000 \mathrm{~km}^{2}$ ) and ii) the river basin scale, from 50 to $600 \mathrm{~km}^{2}$. An analysis at the regional scale allows us first to analyse the global spatial patterns of knotweed distribution (e.g., geology, climate). The choice of the river basin scale was motivated by both biophysical arguments and matters of river management. This scale enables us to consider the spatial dispersion of knotweeds in a highly connected network with a high organization of abiotic factors from upstream to downstream. Indeed, fluvial forces set the physical forcing in communities and are organized at the basin scale from headwater streams to large rivers. Furthermore, the river-basin scale is the most relevant scale for sustainable and integrated aquatic ecosystem management. A better understanding of drivers at this scale could provide more relevant tools for planning the management of rivers. As part of a regional approach, we made the assumption that knotweeds have been introduced in all basins over the last century. Thus, this study aims to explain the variability of its dispersion. Moreover, here, we only consider the transfer of knotweeds from upstream to downstream, without taking into account the contiguity of the river catchments.

In this study, we began with an analysis of the spatial distribution of knotweeds at the regional scale, i.e., at the hydro-ecoregion scale. At the river basin scale, we conducted a logistic regression (LR) to identify the combination of variables explaining knotweed occurrence in river basins. These results will strengthen our knowledge about knotweed colonization throughout the river network and will provide statistical models for evaluating the invasibility of Asian knotweeds at the river basin scale. Given the strong presence of knotweeds in France, this research is an important step to answer the operational questions of managers while taking into account the biophysical and anthropic context of river basins: namely, once management of knotweeds is deemed necessary (Rouifed and Cottet, 2019), where should one act and concentrate efforts and where should one let go? (Dommanget et al., 2019).

\section{Materials and methods}

\subsection{Study species}

Two species of knotweed, F. japonica and F. sachalinensis, were introduced into Europe in the nineteenth century by human intervention, after which they hybridized and formed a species complex now considered invasive (Bailey and Conolly, 1985). Initially imported for their melliferous, foraging, and ornamental qualities, these species became very popular among horticulturists and within botanical gardens at the end of the nineteenth century and were distributed throughout France (F. Piola, personal communication). The cultivation of these species in sympatry has led to the production of their hybrid $F . \times$ bohemica as well as interspecific hybridizations and introgressions with parental species, leading to considerable genetic diversity, escape, and naturalization (supplementary data). The species complex continuously generates new individuals because sexual reproduction is now frequent and efficient (Lamberti-Raverot et al., 2019). Morphologically, it becomes very difficult to distinguish individuals, so we have chosen to treat the complex as a single entity. Moreover, recent works show that the taxa are all found in similar environments (Rouifed et al., 2014; LambertiRaverot et al., 2019).

\subsection{Study area}

Our study area is part of the Rhone-Mediterranean-Corsica (RMC) basin, located in France (Fig. 1A, B). The variety of physiographic, climatic and human factors makes the RMC basin a very diversified territory that includes a large range of environmental factors for consideration in this study. The RMC basin covers $138,450 \mathrm{~km}^{2}$, i.e., $28 \%$ of the French territory, with 11,000 rivers and $1000 \mathrm{~km}$ of coastline. The river network is dense, and the river morphology is diverse (meandering and braided rivers, large alluvial rivers and torrents). The RMC basin is located between five mountain ranges: the Jura, the Vosges, the Massif Central, the Alps, and the Pyrenees. The water resources of this area are therefore both important and diverse, i.e., the RMC basin is fed by rain as well as by meltwater from glaciers and snow. The basin also contains a large number of bodies of water, great diversity of groundwater bodies, and rich and varied wetlands.

In 2006, $55 \%$ of the RMC basin was covered by forested and seminatural areas, $37.5 \%$ by agriculture, and $5.5 \%$ by urbanized areas. The RMC basin is currently subject to increasing anthropic pressure as it undergoes massive touristic and urban development (14 million inhabitants in 2011). This raises major challenges in terms of both pollution and water resource management. This development also affects the river morphology (e.g., dams for energy production, river embankments for roads and railway buildings). For instance, approximately 20,000 weirs and dams punctuate the RMC basin's hydrographic network. Beyond the fact that these obstacles limit ecological and sedimentary continuity, they are also a sign of the historical human settlement along rivers that can favour the dispersion of knotweeds at many river locations in the RMC basin.

\subsection{Datasets}

A comprehensive mapping of the spatial distribution of knotweeds was conducted in 2000-2001 at the request of the RMC's Water Agency. The database (Fig. 2A) provides an understanding of knotweed invasion for (1) river reaches with a Strahler rank of 3 if the reaches are longer than $29 \mathrm{~km}$ and (2) all reaches with a Strahler rank larger than 4. Field observation efforts over such a vast territory for every small stream $($ rank $<3$ ) would have been immense or even impossible. This constraint probably led to an underestimation of the invasion in the studied catchment areas.

The knotweed distribution map has a linear resolution of $1 \mathrm{~km}$. Private agencies conducted most of the survey during the vegetative period (Boyer, 2002). Local organizations (382) were also contacted, among which were 242 intermunicipal structures. These organizations provided information for 29 rivers. Knotweed density was classified into four classes: absence, sporadic, moderate, and high density. This classification was used in the first part of the study, but was then eschewed for the presence/absence (binary) data that we deemed more robust to build the statistical models. In total, 185 rivers (total river length of $11,427 \mathrm{~km}$ ) were prospected. F. japonica, F. sachalinensis, and $F . \times$ bohemica were inventoried. During field surveys, additional data were collected, such as bank erodibility and artificialization, riparian vegetation width and continuity, and channel rectification (Table 1). This database thus constitutes a unique, large-scale, vectorized, and georeferenced source of information about the density of knotweeds as well as several further abiotic factors.

Environmental databases are available in France and provide an exhaustive set of explanatory variables (summary of the variables in Table 1). To provide a unique and homogeneous database, we homogenized all databases with GIS tools (ArcGis ${ }^{\circledR}$ ) at the RHT resolution (i.e., Theoretical Hydrographic Network database). The RHT database (Pella et al., 2012) provides the main abiotic factors of rivers and their catchments in France, including climate, relief, and hydrological regime (spatial extrapolations of a dense gauging network; Sauquet and Catalogne, 2012). RHT is an oriented hydrographic network with defined flow directions. RHT was created on the basis of the hydrographic national reference network BD Carthage ${ }^{\circledR}$ and the $50 \mathrm{~m}$ digital elevation model from the BD Alti®, both developed by IGN (National Institute of Geographical and Forest Information), the Météo France database (https://publitheque.meteo.fr), and the Banque Hydro database (www. hydro.eaufrance.fr). The RHT database segments the French hydrographic network into ca. 115,000 river reaches; a reach is defined here 

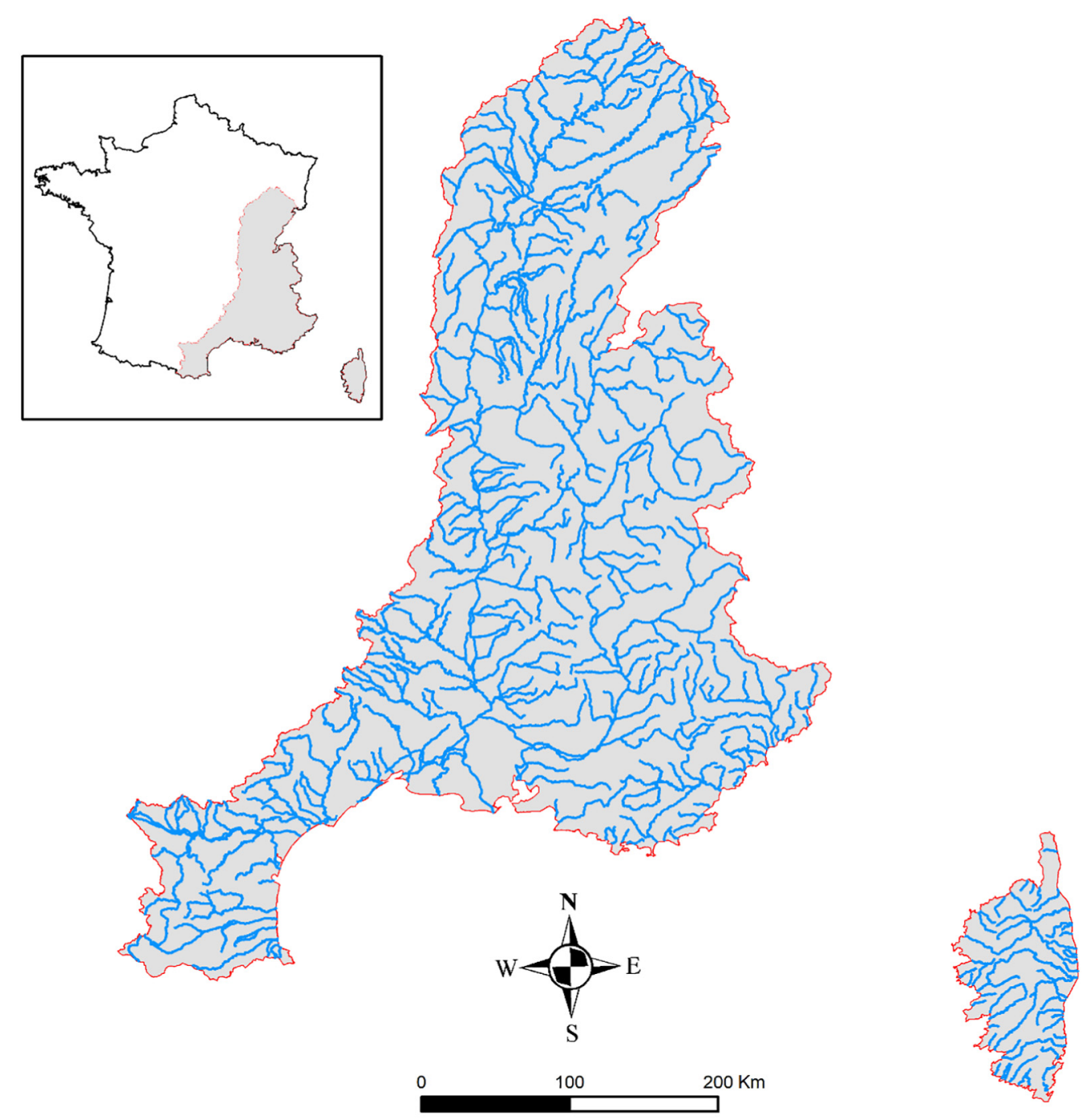

Source : BD Carthage

Fig. 1. Rhône Mediterranean and Corse basins (RMC) in France.

as a stream segment located between two confluences with an average length of $2.5 \mathrm{~km}$. First, the initial 1-km-resolution knotweed observations were aggregated at the reach scale. The qualitative variables (absence, sporadic, moderate, and high density) were converted into quantitative variables $(0,1,2,3)$ and then averaged at the river reach scale. RHT was next combined with information from other national databases (Table 1): i) Corine Land Cover for information on land use and land cover in the river corridor; ii) the Eau France database from the Ministry for the Ecological and Solidary Transition (www.sandre. eaufrance.fr); iii) the INSEE dataset (www.insee.fr) for the human pressure variables; iv) the ROE database (www.sandre.eaufrance.fr), which provides information on weirs, dams, and other obstacles to river flow; v) the SYRAH database (Chandesris et al., 2008) for the hydrological and hydrogeomorphological variables; and vi) the BRGM (www.brgm.fr) and INRA (www.gissol.fr) databases for the geology and lithology, respectively.

The final dataset provides the density of knotweeds and the explanatory variables over the RMC basin for 4998 river reaches and their catchments. Two variables described the level of knotweed colonization of each river basin: i) the fraction of the total river network length occupied by knotweeds in the river basin, and ii) more simply, the presence or absence of knotweeds in the basin. "Basin" explanatory variables describe the basin-scale characteristics for each river reach (e.g., geology, lithology, relief, hydrology, LULC, and climatic characteristics, such as the mean monthly temperatures or monthly rainfalls). Hydrological variables are considered "basin" variables: minimum specific monthly discharge, mean interannual specific discharge, specific bankfull discharge, ten-year return period peak discharge, minimum five-year return period monthly discharge, and flow-duration curve. We also estimated "buffer-basin" explanatory variables for each river reach to focus on the characteristics of the river corridor located upstream of each river reach: LULC, human pressure, and geology. The river corridor is defined here as a strip with a width equal to 6 times the bankfull width. In this buffer area, we estimated "buffer-basin" variables, such as the fraction of agricultural lands, wetlands, water bodies, artificial lands and forested areas (Table 1).

\subsection{Statistical analyses at the hydro-ecoregion scale}

We first tested the hypothesis that geology, climate, and relief factors would control the spatial distribution of knotweeds at a regional scale $\left(350-33,000 \mathrm{~km}^{2}\right)$. We used the hydro-ecoregion classification (denoted HER) first introduced by the US Environmental Protection Agency (US EPA; Frissell et al., 1986) and later developed in France (Wasson et al., 2002). The HER provides a functional, regionalized, and prioritized system that enables the identification of geographic entities in which flowing-water ecosystems have common characteristics (Wasson et al., 2002). Two levels of classification were considered in 

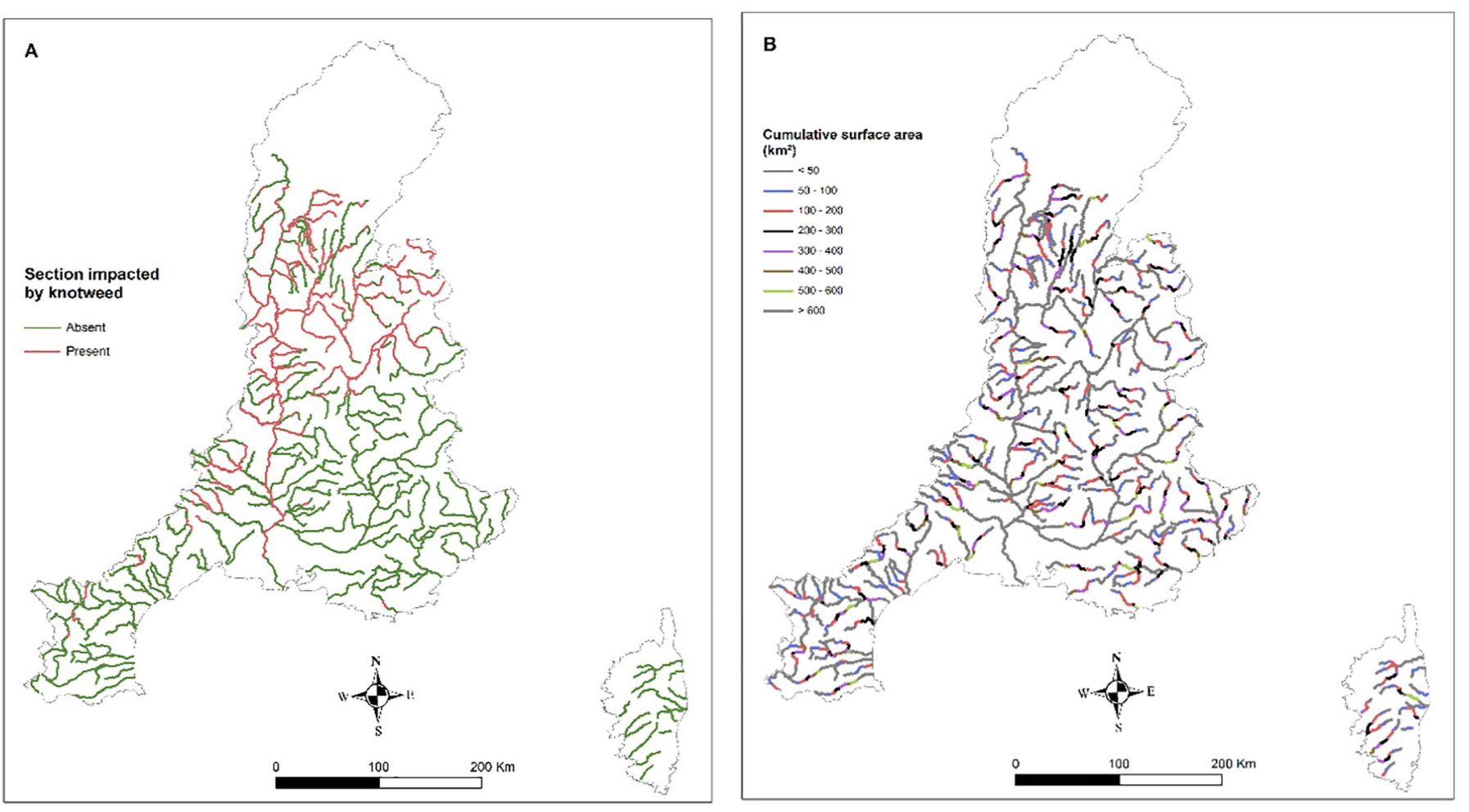

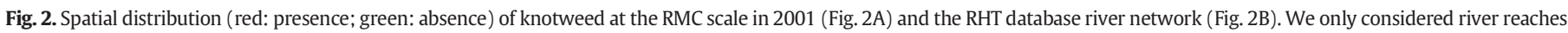

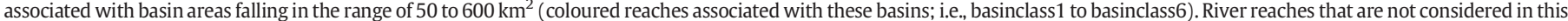
study are plotted in grey $\left(<50 \mathrm{~km}^{2}\right.$ and $\left.>600 \mathrm{~km}^{2}\right)$. (For interpretation of the references to colour in this figure legend, the reader is referred to the web version of this article.)

this study:. HER-1 with 15 homogeneous regions located in the RMC basin and a more detailed HER-2, with ca. 65 subregions. We estimated for each HER: i) the number of river reaches with knotweeds present (expressed in percent of the total number of reaches for each HER); ii) the total river network length populated by knotweeds (expressed in percent of the total river length in each HER); and iii) the distribution of each explanatory variable estimated at reach scale (weighted by the reach length). We then sought to identify the main factors explaining the density of knotweeds in these regions.

\subsection{Statistical modelling at the river basin scale}

We conducted a similar analysis at a smaller scale, i.e., at the river basin scale, from 50 to $600 \mathrm{~km}^{2}$. River basins falling within the same range of drainage area were sampled among all the RMC river basins in the RHT. Six basin classes were considered: the $50-100 \mathrm{~km}^{2}$ class was designated as "basinclass1"; $100-200 \mathrm{~km}^{2}$ as "basinclass2"; 200-300 km² as "basinclass3"; $300-400 \mathrm{~km}^{2}$ as "basinclass4"; $400-500 \mathrm{~km}^{2}$ as "basinclass5"; and $500-600 \mathrm{~km}^{2}$ as "basinclass6". In the case of nested basins belonging to the same basin-size class, we only kept the smallest basin. This selection enabled us to avoid any observational redundancy within each basin-size class and any spatial autocorrelation. This range of basin sizes is relevant for river basin management plans to prevent the spread of invasive species, and it allows us to consider sample sizes large enough for robust statistical analyses (minimum sample size $>40$; Table 2 ). However, the inherent limitation of this approach is that larger rivers located further downstream in the hydrosystem, such as Rhône's main channel and its main tributaries, i.e., the Ain, Saône, Isère, Drôme, Ardèche and Durance rivers, were not considered in this study (grey line in Fig. 2B).

For each basin-size class ("basinclass1" to "basinclass6"), statistical analyses were undertaken to identify a combination of explanatory variables that would best predict knotweed density in the basin (qualitative
$Y$-response random variable). Because of the very uneven distribution of the knotweed density data and the sample size, only the presence (aggregation of sporadic, moderate, and high-density classes) and absence of knotweeds were used. $Y$ can take two modalities: $Y=1$, i.e., "presence of knotweeds in the river-basin" or $Y=0$, i.e., "absence of knotweeds in the river-basin". We deployed a logistic regression to estimate the probability $p$ that knotweeds are present in a watershed from a linear combination of a set of explanatory variables $X_{i}$ (basin or buffer-basin variables). The main hypothesis of the logistic regression model is that the logit $(p)$, i.e., $\log (p /(1-p))$ function is a linear combination of the explanatory variables $X_{i}$ such that:

$\log \left(\frac{p}{1-p}\right)=K 0+\sum_{1=1}^{n} K_{i} X_{i}$

where $n$ is the number of explanatory variables $X_{i}$ and $K_{i}$ is the $i$ th linear coefficient. The probability $p$ of belonging to the "presence" basin group is then given by:

$p=\frac{e^{K 0+\sum_{i=1}^{n} K_{i} X_{i}}}{1+e^{K 0+\sum_{i=1}^{n} K_{i} X_{i}}}$

This logistic regression model was implemented under $R$ software ( $R$ Core Team, 2017) using the generalized linear model (GLM), the glm \{stat\} function, and the logit binomial model. GLM models provide a probability $p$ of knotweed "presence". Each model is therefore associated with a cut-off point defining whether $Y$ takes the "presence" or "absence" mode. By default, we used a cut-off point of 0.5; i.e., the GLM model predicts a probability of $50 \%$ or more that knotweed is present when classed in the "presence" group. We tested the sensitivity of the models to the choice of the cut-off point.

The choice of explanatory variables used to build the final model depends not only on statistical criteria but also on biological and operational considerations. We verified that each of the selected explanatory 
Table 1

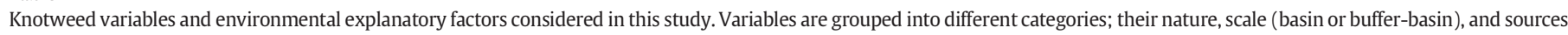
are also indicated. The selection of the variables at each step of the analysis is indicated by a bullet point.

\begin{tabular}{|c|c|c|c|c|c|c|c|c|c|}
\hline Category & Id & Description & $\begin{array}{l}\text { BASsin/BUFfer } \\
\text { variables }\end{array}$ & $\begin{array}{l}\text { QUALitative/ } \\
\text { QUANTitative } \\
\text { variables }\end{array}$ & $\begin{array}{l}\text { Database } \\
\text { used }\end{array}$ & $\begin{array}{l}\text { Independent } \\
\text { variables } \\
\text { (Pearson test) }\end{array}$ & $\begin{array}{l}\text { Wald Test and } \\
\text { Likelihood Ratio } \\
\text { Test }\end{array}$ & $\begin{array}{l}\text { Model } \\
300-400 \mathrm{~km}^{2}\end{array}$ & OpModel \\
\hline Knotweed & KnotPres\% & $\begin{array}{l}\text { Percent of reach length } \\
\text { with knotweeds (\%) }\end{array}$ & BAS & QUANT & Boyer & - & & & \\
\hline Knotweed & KnotPres & $\begin{array}{l}\text { Presence or absence of } \\
\text { knotweeds in the basin }\end{array}$ & BAS & QUAL & Boyer & - & & & \\
\hline Climate & $\begin{array}{l}\text { TempJan, } \\
\text { TempJul }\end{array}$ & $\begin{array}{l}\text { Mean temperature in } \\
\text { January and July }\left({ }^{\circ} \mathrm{C}\right)\end{array}$ & BAS & QUANT & $\begin{array}{l}\text { Meteo } \\
\text { France/RHT }\end{array}$ & & & & \\
\hline Climate & $\begin{array}{l}\text { Rainjan, } \\
\text { RainFeb... } \\
\text { RainDec }\end{array}$ & $\begin{array}{l}\text { Monthly precipitations, } \\
\text { January to December } \\
\text { (mm/month) }\end{array}$ & BAS & QUANT & $\begin{array}{l}\text { Meteo } \\
\text { France/RHT }\end{array}$ & & & & \\
\hline Climate & $\begin{array}{l}\text { RainSum, } \\
\text { RainWin, RainFal, } \\
\text { RainSpr }\end{array}$ & $\begin{array}{l}\text { Seasonal precipitations } \\
\text { (mm/season) }\end{array}$ & BAS & QUANT & $\begin{array}{l}\text { Meteo } \\
\text { France/RHT }\end{array}$ & • RainWin/RainSum & RainWin/RainSum & • RainSum & RainSum \\
\hline Relief & AltiMean & $\begin{array}{l}\text { Mean altitude of the basin } \\
\text { (m, a.s.l.) }\end{array}$ & BAS & QUANT & $\begin{array}{l}\text { BD } \\
\text { Topo/RHT }\end{array}$ & - & & & \\
\hline Relief & DrainArea & Drainage area $\left(\mathrm{km}^{2}\right)$ & BAS & QUANT & RHT & & & & \\
\hline Relief & DrainSlope & $\begin{array}{l}\text { Mean slope of river } \\
\text { network }(\mathrm{m} / \mathrm{m})\end{array}$ & BAS & QUANT & $\begin{array}{l}\text { BD } \\
\text { Topo/RHT }\end{array}$ & & & & \\
\hline Hydrology & QMonthMin & $\begin{array}{l}\text { Minimum specific monthly } \\
\text { discharge }\left(\mathrm{m}^{3} / \mathrm{s} / \mathrm{km}^{2}\right)\end{array}$ & BAS & QUANT & $\begin{array}{l}\text { Banque } \\
\text { Hydro/RHT }\end{array}$ & & & & \\
\hline Hydrology & QMean & $\begin{array}{l}\text { Specific mean interannual } \\
\text { discharge }\left(\mathrm{m}^{3} / \mathrm{s} / \mathrm{km}^{2}\right)\end{array}$ & BAS & QUANT & $\begin{array}{l}\text { Banque } \\
\text { Hydro/RHT }\end{array}$ & - & • & & \\
\hline Hydrology & QBankfull & $\begin{array}{l}\text { Specific bankfull discharge } \\
\left(\mathrm{m}^{3} / \mathrm{s} / \mathrm{km}^{2}\right)\end{array}$ & BAS & QUANT & SYRAH & & & & \\
\hline Hydrology & Q05, Q50, Q95 & $\begin{array}{l}\text { Specific } 5,50 \text { and } 95 \% \\
\text { exceedance time discharge } \\
\text { on flow duration curves } \\
\left(\mathrm{m}^{3} / \mathrm{s} / \mathrm{km}^{2}\right)\end{array}$ & BAS & QUANT & $\begin{array}{l}\text { Banque } \\
\text { Hydro/RHT }\end{array}$ & & & & \\
\hline Hydrology & QMNA5 & $\begin{array}{l}\text { Minimum monthly } \\
\text { discharge with } 5 \text {-yr return } \\
\text { period }\left(\mathrm{m}^{3} / \mathrm{s} / \mathrm{km}^{2}\right)\end{array}$ & BAS & QUANT & $\begin{array}{l}\text { Banque } \\
\text { Hydro/RHT }\end{array}$ & - & & & \\
\hline Hydrology & Q10 & $\begin{array}{l}\text { Flood discharge with } 10-\mathrm{yr} \\
\text { return period }\left(\mathrm{m}^{3} / \mathrm{s} / \mathrm{km}^{2}\right)\end{array}$ & BAS & QUANT & $\begin{array}{l}\text { Banque } \\
\text { Hydro/RHT }\end{array}$ & - & & & \\
\hline Geomorphology & EroBanks & $\begin{array}{l}\text { Bank erosion (from low to } \\
\text { high; } 3 \text { classes) }\end{array}$ & BAS & QUAL & Boyer & - & • & - & \\
\hline Geomorphology & StreamP & $\begin{array}{l}\text { Specific stream power } \\
\left(\mathrm{N} / \mathrm{m}^{2}\right)\end{array}$ & BAS & QUANT & SYRAH & - & - & & • \\
\hline Geology & $\begin{array}{l}\text { GeolSedim, } \\
\text { GeolVolc, } \\
\text { GeolMeta }\end{array}$ & $\begin{array}{l}\text { Sedimentary, volcanic, } \\
\text { metamorphic rocks (\%) }\end{array}$ & BUF & QUANT & BRGM & - & & & \\
\hline Lithology & $\begin{array}{l}\text { LithLoose, } \\
\text { LithClay, } \\
\text { LithMarl, } \\
\text { LithHetero }\end{array}$ & $\begin{array}{l}\text { Lithology in the basin } \\
\text { (loose soils, clayed, marl, } \\
\text { heterogeneous carbonates, } \\
\% \text { ) }\end{array}$ & BAS & QUANT & INRA & • & - LithLoose & & \\
\hline Lithology & $\begin{array}{l}\text { LithImper, } \\
\text { LithPerv }\end{array}$ & $\begin{array}{l}\text { Impervious and pervious } \\
\text { lithology }(\%)\end{array}$ & BAS & QUANT & SYRAH & - & & & \\
\hline Land use & RiparBanks & $\begin{array}{l}\text { Riparian vegetation width } \\
\text { (from high to low; } 4 \\
\text { classes) }\end{array}$ & BUF & QUAL & Boyer & - & & & \\
\hline Land use & ContiBanks & $\begin{array}{l}\text { Riparian vegetation } \\
\text { continuity (from high to } \\
\text { low; } 4 \text { classes) }\end{array}$ & BUF & QUAL & Boyer & & & & \\
\hline Land use & $\begin{array}{l}\text { AgriBuff, } \\
\text { WetlaBuff, } \\
\text { WaterBuff, } \\
\text { ArtifBuff, } \\
\text { ForestBuff }\end{array}$ & $\begin{array}{l}\text { Agricultural, wetlands, } \\
\text { water bodies, artificial, and } \\
\text { forested areas in a buffer } \\
\text { along river (\%) }\end{array}$ & BUF & QUANT & $\begin{array}{l}\text { CORINE } \\
\text { Land Cover }\end{array}$ & $\begin{array}{l}\text { - ArtifBuff, } \\
\text { ForestBuff }\end{array}$ & $\begin{array}{l}\text { - ArtifBuff, } \\
\text { ForestBuff }\end{array}$ & $\begin{array}{l}\text { - ArtifBuff, } \\
\text { ArtiffBanks } \\
\text { ForestBuff }\end{array}$ & $\begin{array}{l}\text { ArtifBuff, } \\
\text { ForestBuff }\end{array}$ \\
\hline Land use & VegBuffer & $\begin{array}{l}\text { Vegetation in the buffer } \\
\text { area (\%) }\end{array}$ & BUF & QUANT & $\begin{array}{l}\text { CORINE } \\
\text { Land Cover }\end{array}$ & & & & \\
\hline Land use & $\begin{array}{l}\text { AgriBasin, } \\
\text { WetlaBasin, } \\
\text { WaterBasin, } \\
\text { ArtifBasin, } \\
\text { ForestBasin }\end{array}$ & $\begin{array}{l}\text { Agricultural, wetlands, } \\
\text { water bodies, artificial, and } \\
\text { forested areas in the } \\
\text { river-basin (\%) }\end{array}$ & BAS & QUANT & $\begin{array}{l}\text { CORINE } \\
\text { Land Cover }\end{array}$ & - & - ArtiBasin & & \\
\hline Human-pressure & ArtifBanks & $\begin{array}{l}\text { Bank artificialisation (low } \\
\text { to high; } 4 \text { classes) }\end{array}$ & BUF & QUAL & Boyer & - & - & & \\
\hline Human-pressure & RectifChannel & Natural or rectified channel & BUF & QUAL & Boyer & & & & \\
\hline Human-pressure & ObstNumb & $\begin{array}{l}\text { Number of obstacles in the } \\
\text { basin }\end{array}$ & BAS & QUANT & ROE & & & & \\
\hline Human-pressure & ObstDens & $\begin{array}{l}\text { Mean density of obstacle in } \\
\text { the basin (number of } \\
\text { obstacle } / \mathrm{m} \text { ) }\end{array}$ & BAS & QUANT & ROE & • & - & - & • \\
\hline
\end{tabular}


Table 1 (continued)

\begin{tabular}{|c|c|c|c|c|c|c|c|c|c|}
\hline Category & Id & Description & $\begin{array}{l}\text { BASsin/BUFfer } \\
\text { variables }\end{array}$ & $\begin{array}{l}\text { QUALitative/ } \\
\text { QUANTitative } \\
\text { variables }\end{array}$ & $\begin{array}{l}\text { Database } \\
\text { used }\end{array}$ & $\begin{array}{l}\text { Independent } \\
\text { variables } \\
\text { (Pearson test) }\end{array}$ & $\begin{array}{l}\text { Wald Test and } \\
\text { Likelihood Ratio } \\
\text { Test }\end{array}$ & $\begin{array}{l}\text { Model } \\
300-400 \mathrm{~km}^{2}\end{array}$ & OpModel \\
\hline Human-pressure & PopBasin & $\begin{array}{l}\text { Total population in the } \\
\text { river basin }\end{array}$ & BUF & QUANT & INSEE & & & & \\
\hline Human-pressure & AnthroPress & Anthropic pressure (\%) & BUF & QUANT & BD TOPO & & & & \\
\hline Human-pressure & WastePlant & $\begin{array}{l}\text { Number of waste water } \\
\text { treatment plant }\end{array}$ & BAS & QUANT & Eau France & • & & & \\
\hline Human-pressure & EcoloState & $\begin{array}{l}\text { Ecological state of water } \\
\text { bodies ( } 4 \text { classes) }\end{array}$ & BAS & QUAL & Eau France & & & & \\
\hline Human-pressure & ChimicState & $\begin{array}{l}\text { Chemical state of water } \\
\text { bodies ( } 2 \text { classes) }\end{array}$ & BAS & QUAL & Eau France & & & & \\
\hline
\end{tabular}

variables was consistent with our knowledge of knotweed biology (detailed in the introduction to this paper) and consistent with each other. Finally, among all the collinear variables $(R>0.5)$, we chose the explanatory variables that, as much as possible, can be collected in the field, via GIS, or by remote sensing at the lowest cost and by limiting the biases and errors of the operators during data collection. This approach would allow the models to be implemented easily and in a harmonized manner by river basin managers and water agencies.

First, only explanatory variables with very few missing values were kept. Second, a logistic regression model based on GLM assumes that the predictive variables $X_{i}$ are independent; therefore, redundancy between variables was strictly avoided. To test the redundancy of information, we calculated the Pearson correlation coefficient for each pair of predictive variables to keep only the variables with the lowest correlation between each other. We set the limit of this correlation coefficient at 0.5 (in absolute value) to limit the linear dependence between variables.

To select the most relevant explanatory variable subset for each basin-class model, the "null model" (i.e., no explanatory variable) and the GLM model were applied to each variable individually and statistically compared using the Wald test (WT) and the likelihood ratio test (LRT). The WT tests the true value of the model parameter, while the LRT is used to decide whether to reject the null model in favour of the substitution model with an explanatory variable. The probabilities of these two tests were corrected with the Holm-Bonferroni method for considering statistical inference problems in multiple tests. Variables with $p<0.05$ were used to construct a specific model for each basinsize class. The models are designated as "Model1 50-100", i.e., the model based on basin-size class [50-100 km²], "Model2 100-200", "Model3 200-300", "Model4 300-400", "Model5 400-500" and "Model6 500-600".

Finally, two quality indicators were chosen from the confusion matrix: the model's accuracy and the false positive rate (hereafter FP). Accuracy is defined as the ratio between the number of correctly predicted basins (presence or absence mode) and the total number of basins studied. FP is defined as the ratio between (i) the number of basins predicted to have no knotweed while knotweed was present on the basin and (ii) the total number of basins where knotweed is present. FP is an important piece of information, as it defines the risk that one would take to estimate that a basin is free of knotweed when knotweed is in fact present in the basin. Accuracy and FP were also calculated by applying the different models ("Model1 50-100" to "Model6 500-600") to the other basin classes. This validation step verifies the robustness of the models and their sensitivity to the basin size. It allows us to define the capacity of the models to be generalized to sizes of drainage area that are greater or smaller than that for which they were calibrated.

\section{Results}

\subsection{Hydro-ecoregion analysis}

The respective numbers of river reaches and the total length of the segments differ widely between HER (see Table A1 in supplementary materials and Fig. 3). Fig. 3 shows a very contrasting inventory. For HER-1 Pyrénées and Corse regions, no knotweeds were observed, whereas in the Plaine de Saône, Jura-Préalpes du Nord and Massif Central Sud regions, approximately $60 \%$ of the river reaches in which information about knotweed presence was available show knotweeds to indeed be present. For two regions (Vosges and Alsace), no data pertaining to knotweed are available. HER-1 and HER-2 both show a global north-to-south decreasing gradient in knotweed density (Fig. 3). The distributions of several explanatory variables differ between HERs (Fig. A1, supplementary files), but at this scale, none of these variables can help in explaining knotweed density variability (Kruskal-Wallis test; $p>0.05$ ).

\section{2. $100-200 \mathrm{~km}^{2}$ basin-scale analysis}

Before applying the logistic regression analysis, we chose to describe and analyse the statistical distribution of the explanatory variables for the $100-200 \mathrm{~km}^{2}$ river-basin class. The level of knotweed invasion for each basin is defined here as the percentage of river length occupied by knotweeds in each basin (from 0 to $100 \%$ ). We classified 176 basins into four classes $(0-25 \%, 25-50 \%, 50-75 \%$ and $75-100 \%$ of knotweed density). Several explanatory variables differed significantly between at least two classes of knotweed density (Kruskal-Wallis post hoc test; $p<0.05$; Fig. 4). Several trends are clear from the analysis presented in Fig. 4 and do not depend on the choice of knotweed density classwidth (sensibility test led with 2, 3, and 4 class widths).

Every climatic variable points in the same direction, i.e., to an increase in the density of knotweed as a result of rainfall (e.g., RainMay; Fig. 4). Hydrological variables, such as the specific bankfull discharge (QBankfull), show a nonlinear trend: knotweed density increases with flood magnitude for the $0-50 \%$ knotweed density classes and then decreases for the $50-100 \%$ density classes. Relations between hydrogeomorphological variables and knotweed density are also clearly in evidence: bank erosion (EroBanks) and stream power (StreamP) are positively linked with

Table 2

Number of watersheds where knotweeds are present (density $>0 \%$ ) or absent $(0 \%)$ for six basin-size samples in the range of $50-600 \mathrm{~km}^{2}$.

\begin{tabular}{|c|c|c|c|c|c|c|}
\hline & $50-100 \mathrm{~km}^{2}$ & $100-200 \mathrm{~km}^{2}$ & $200-300 \mathrm{~km}^{2}$ & $300-400 \mathrm{~km}^{2}$ & $400-500 \mathrm{~km}^{2}$ & $500-600 \mathrm{~km}^{2}$ \\
\hline Presence & 34 & 47 & 45 & 33 & 27 & 22 \\
\hline Absence & 136 & 129 & 78 & 51 & 34 & 24 \\
\hline Total & 170 & 176 & 123 & 84 & 61 & 46 \\
\hline
\end{tabular}




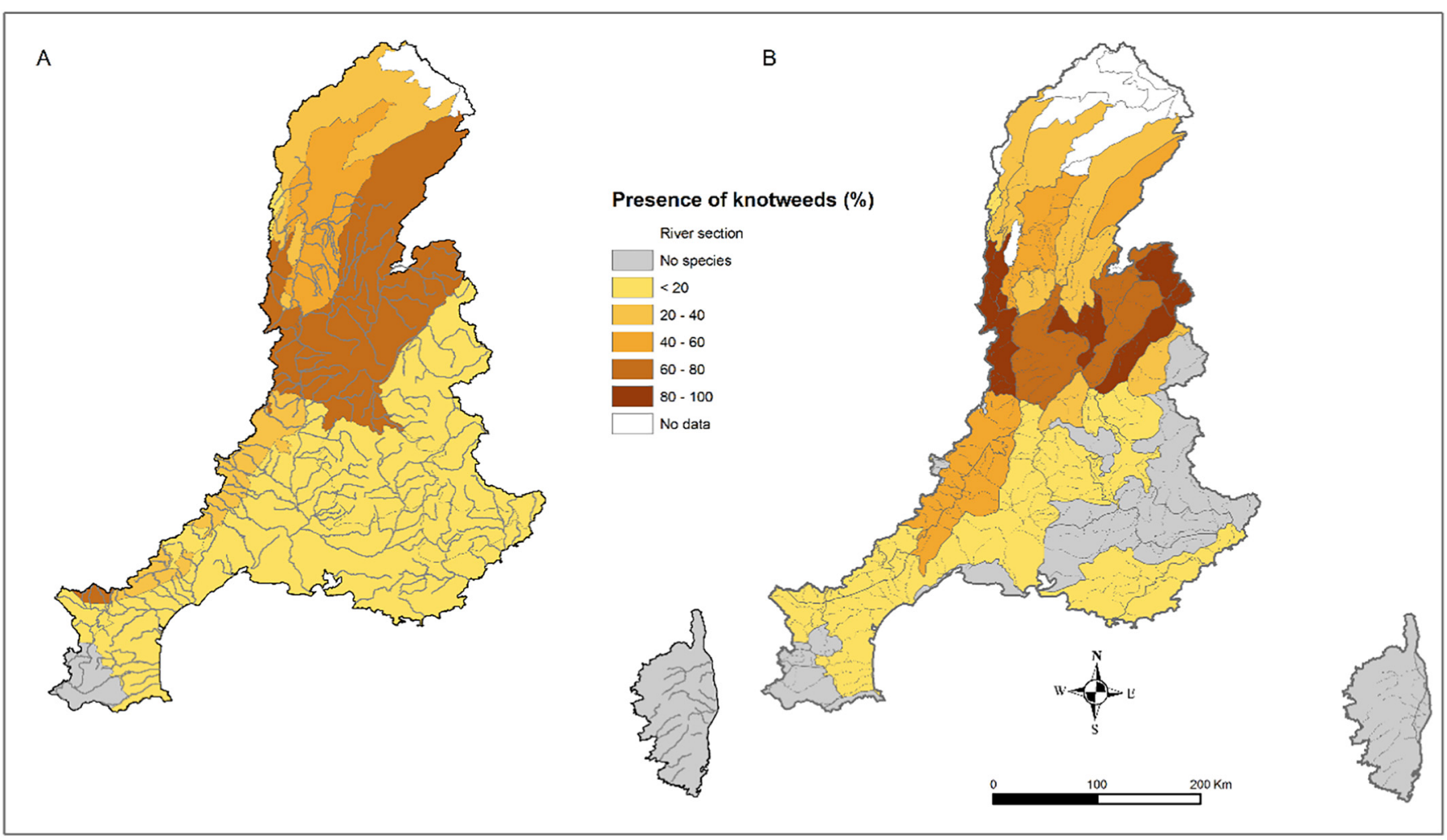

Fig. 3. Knotweed presence (KnotPres\% variable) for HER-1 (Fig. 3A) and HER-2 (Fig. 3B).
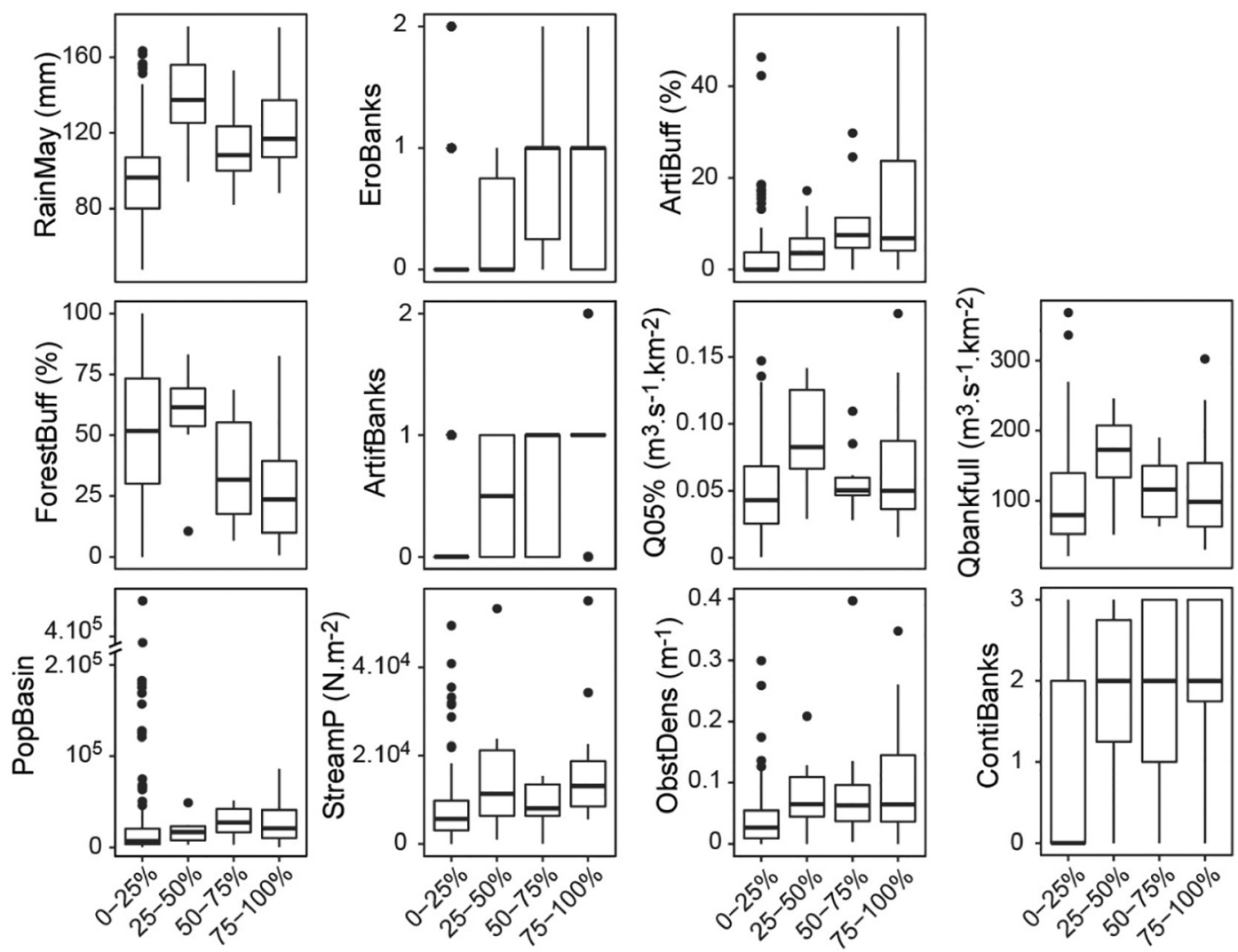

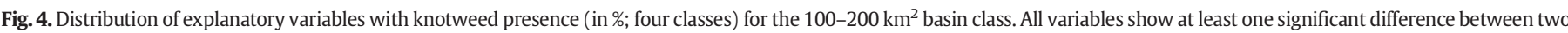
classes of presence with the Kruskal-Wallis post hoc test $(p<0.05)$. 
knotweed density. Knotweed density also shows a positive trend with variables related to human activities (ArtifBuff, ArtifBank, PopBasin, AnthroPress, ObstDens): the greater the human pressures in a basin is, the greater the likelihood of observing knotweed is. Moreover, all variables characterizing forest or riparian vegetation (density or continuity, Table 1) show a unique trend (ContiBanks, RiparBanks, ForestBuff, VegBuffer): the denser and more continuous the bank vegetation is along the river, the fewer knotweeds there are. No variable characterizing the geology or lithology (at the basin scale or at the river buffer scale) emerged from this basin analysis.

\subsection{River-basin scale modelling (50-600 $\left.\mathrm{km}^{2}\right)$}

Only the explanatory variables without missing data were kept in the following analysis; the ecological and chemical indicators (EcoloState, ChimicState) of water bodies were therefore removed. We selected 22 independent variables with Pearson correlation coefficients of $<0.5$ (Table 1; independent variables are indicated with bullet points). The likelihood ratio test (LRT) and Wald test (WT) then provided a subset of 11 significant variables $(p<0.05)$. The selected variables are independent and show a high explanatory potential of knotweed presence/absence (in bold for each basin-size class in Table 3). They relate to climate (winter and summer rainfalls), hydrology (specific mean interannual discharge), lithology (loose soils), hydrogeomorphology (bank erosion and specific stream power), land cover (forest areas in the river corridor or buffer), and land use (artificial areas in the river corridor and the basin, bank artificialisation, and longitudinal density of obstacle).

River basins smaller than $500 \mathrm{~km}^{2}$ with a mean interannual summer rainfall (RainSum) of less than $220 \mathrm{~mm} / \mathrm{yr}$ show an absence of knotweeds at almost every basin scale (Fig. 4). Winter rainfalls (RainWin) are significant when discerning the presence or absence of knotweeds but only in cases in which the basin size is larger than $400 \mathrm{~km}^{2}$ (the limit is $250 \mathrm{~mm} / \mathrm{yr}$; Fig. 5). The mean interannual specific discharge (QMean) is relevant only for the $400-500 \mathrm{~km}^{2}$ basin class. Bank erosion (EroBank) is a useful geomorphological indicator of knotweeds only for basins in the range of $300-500 \mathrm{~km}^{2}$, but $p$-values are close to 0.05 (ranging between 0.049 and 0.073 ) for smaller basins. Specific stream power (StreamP) is also a relevant variable in determining the presence/absence classes for small basin sizes $\left(100-200 \mathrm{~km}^{2}\right.$ and $\left.400-500 \mathrm{~km}^{2}\right)$ : the greater the specific stream power is, the more knotweeds are present in the basin. Forest density in the riparian corridor (ForestBuff) exhibits a unique negative relation: the probability of the presence of knotweeds decreases with the increase in tree and shrub coverage, mainly for basin areas within $50-100 \mathrm{~km}^{2}$ and $300-400 \mathrm{~km}^{2}$. No variable characterizing the geology nor the lithology emerged from this basin analysis, except for one for basins within the $200-300 \mathrm{~km}^{2}$ range; knotweed occurrence increases with the fraction of loose soils in the catchment, i.e., when the relative density of the soil is anywhere from $0 \%$ to $15 \%$. Human pressure variables point in the same direction; the presence of knotweeds is greater as the degree of artificialization of the banks (ArtifBanks), the river corridor (ArtifBuff), and the basin (ArtifBasin) increases. Finally, the presence of knotweeds shows a strong positive trend with the increasing longitudinal density of obstacles (ObstDens) at every basin scale. ObsDens reflects the degree of human impairment and sediment-ecological connectivity of the river network.

The variables kept for each basin class with a $\mathrm{p}<0.05$ (in italics at Table 5) were then used to calibrate the specific model associated with each basin-size class. Table 4 shows the accuracy and FP for the six models. The accuracy of global models is high (>80\%) and can reach $90 \%$ for model300-400 (Table 4 ). All the models are robust, as their accuracy does not depend on the choice of the basin class. FP rates are low (FP $<19 \%)$ for models built on basin-size class $>300 \mathrm{~km}^{2}$. The same models also predict low FPs $(12 \%<\mathrm{FP}<24 \%)$ when tested with the smallest basins $\left(<300 \mathrm{~km}^{2}\right)$. The risk of falsely predicting that a basin does not contain knotweeds when in fact it does is higher for smaller basins (50-300 $\mathrm{km}^{2}$ ) with FP falling in the range of $31-47 \%$. However, when these models are applied to larger basin datasets $\left(300-600 \mathrm{~km}^{2}\right)$, they show FP in the range of $23-67 \%$. The model built on the $300-400 \mathrm{~km}^{2}$ basin class seems to be a good compromise between model accuracy ( $90 \%$ ) and low false positive FP rate (13\%). This model produces FP $<24 \%$ for other river basin datasets and can be expressed as follows:

$$
\begin{aligned}
\log \left(\frac{p}{1-p}\right)= & -7.736+1.128 \cdot \text { ArtifBanks }+0.653 \cdot \text { EroBanks } \\
& +0.093 \cdot \text { ArtifBuff }-0.014 \cdot \text { ForestBuff }+59.184 \cdot \text { ObstDens } \\
& +0.019 \cdot \text { RainSum }
\end{aligned}
$$

where ArtifBanks is the artificial area in the river corridor, EroBanks is the bank erodibility, ArtifBuff is the artificialization in the river corridor, ForestBuff is the forest area in the buffer, ObstDens is the longitudinal density of obstacles in rivers, and RainSum is the interannual summer rainfall. The presence of knotweed is thus positively correlated with (i) the climate variable (RainSum); (ii) geomorphological variable (EroBanks); and (iii) human impairment variables on the banks, river corridor, and main channel (respectively ArtifBanks, ArtifBuff, and ObstDens) but negatively correlated with the density of riparian forest (ForestBuff).

Each model is associated with a cut-off point to separate the "presence" and "absence" classes (set by default at 0.5 for the previous analyses). Sensitivity tests conducted for all the estimated models show that the cut-off point does not influence the accuracy and FP of models (Fig. A1). A cut-off point of 0.5 was chosen.

As mentioned earlier, the choice of model variables can be made according to statistical criteria (accuracy, FP) and biological knowledge of knotweeds but with reference to more practical and operational criteria, such as the ease with which river managers estimate the explanatory

Table 3

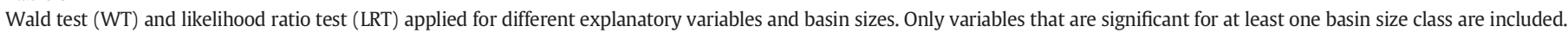

\begin{tabular}{|c|c|c|c|c|c|c|c|c|c|c|c|c|c|}
\hline \multirow[t]{2}{*}{ Id. } & \multirow[t]{2}{*}{ Variables } & \multicolumn{2}{|c|}{$50-100 \mathrm{~km}^{2}$} & \multicolumn{2}{|c|}{$100-200 \mathrm{~km}^{2}$} & \multicolumn{2}{|c|}{$200-300 \mathrm{~km}^{2}$} & \multicolumn{2}{|c|}{$300-400 \mathrm{~km}^{2}$} & \multicolumn{2}{|c|}{$400-500 \mathrm{~km}^{2}$} & \multicolumn{2}{|c|}{$500-600 \mathrm{~km}^{2}$} \\
\hline & & WT & LRT & WT & LRT & WT & LRT & WT & LRT & WT & LRT & WT & LRT \\
\hline RainWin & Winter rainfall & $5.8 \mathrm{E}-1$ & $6.4 \mathrm{E}-1$ & $1.2 \mathrm{E}-1$ & $1.2 \mathrm{E}-1$ & $2.3 \mathrm{E}-1$ & $2.0 \mathrm{E}-1$ & $8.5 \mathrm{E}-1$ & $7.9 \mathrm{E}-1$ & $3.7 E-2$ & $8.3 E-3$ & $3.8 \mathrm{E}-2$ & $2.6 \mathrm{E}-4$ \\
\hline RainSum & Summer rainfall & $2.8 \mathrm{E}-5$ & $6.8 \mathrm{E}-7$ & $6.4 \mathrm{E}-6$ & $2.7 \mathrm{E}-8$ & $7.6 \mathrm{E}-4$ & $1.6 \mathrm{E}-5$ & $3.5 \mathrm{E}-3$ & $4.4 E-5$ & $2.0 \mathrm{E}-2$ & $4.4 \mathrm{E}-7$ & $1.4 \mathrm{E}-1$ & $8.3 \mathrm{E}-3$ \\
\hline QMean & Mean interannual specific discharge & $4.3 \mathrm{E}-1$ & $4.6 \mathrm{E}-1$ & $6.8 \mathrm{E}-2$ & $6.0 \mathrm{E}-2$ & $1.0 \mathrm{E}+0$ & $1.0 \mathrm{E}+0$ & $1.0 \mathrm{E}+0$ & $1.0 \mathrm{E}+0$ & $3.7 E-2$ & 7.1E-3 & $1.6 \mathrm{E}-1$ & $4.1 \mathrm{E}-2$ \\
\hline LithLoose & Lithology in the basin & $8.2 \mathrm{E}-1$ & $8.5 \mathrm{E}-1$ & $1.0 \mathrm{E}+0$ & $1.0 \mathrm{E}+0$ & $2.4 \mathrm{E}-2$ & $3.6 \mathrm{E}-3$ & $9.3 \mathrm{E}-1$ & $8.2 \mathrm{E}-1$ & $1.0 \mathrm{E}+0$ & $1.0 \mathrm{E}+0$ & $1.0 \mathrm{E}+0$ & $1.0 \mathrm{E}+0$ \\
\hline StreamP & Specific stream power & $1.6 \mathrm{E}-1$ & $1.3 \mathrm{E}-1$ & $7.9 \mathrm{E}-3$ & $1.5 \mathrm{E}-3$ & $6.1 \mathrm{E}-1$ & $2.6 \mathrm{E}-1$ & $7.5 \mathrm{E}-2$ & $2.0 \mathrm{E}-2$ & $1.0 \mathrm{E}+0$ & $7.0 \mathrm{E}-1$ & $1.0 \mathrm{E}+0$ & $5.1 \mathrm{E}-1$ \\
\hline EroBank & Bank erosion & $5.0 \mathrm{E}-2$ & $5.1 \mathrm{E}-2$ & $7.2 \mathrm{E}-2$ & $7.0 \mathrm{E}-2$ & $7.3 \mathrm{E}-2$ & $4.9 \mathrm{E}-2$ & $1.0 \mathrm{E}-2$ & $6.5 E-4$ & $1.4 \mathrm{E}-2$ & $5.2 \mathrm{E}-4$ & $3.8 \mathrm{E}-1$ & $9.9 \mathrm{E}-2$ \\
\hline ForestBuff & Forested area in the buffer & $3.1 \mathrm{E}-2$ & $1.9 \mathrm{E}-2$ & $1.7 \mathrm{E}-1$ & $1.5 \mathrm{E}-1$ & $1.5 \mathrm{E}-1$ & $1.2 \mathrm{E}-1$ & $5.0 \mathrm{E}-2$ & $2.5 \mathrm{E}-2$ & $1.0 \mathrm{E}+0$ & $8.1 \mathrm{E}-1$ & $1.0 \mathrm{E}+0$ & $1.0 \mathrm{E}+0$ \\
\hline ArtifBasin & Artificial area in the basin & $1.4 \mathrm{E}-1$ & $4.5 \mathrm{E}-2$ & $1.3 \mathrm{E}-2$ & $4.2 \mathrm{E}-3$ & $1.0 \mathrm{E}+0$ & $7.5 \mathrm{E}-1$ & $8.4 \mathrm{E}-1$ & $5.2 \mathrm{E}-1$ & $1.0 \mathrm{E}+0$ & $1.0 \mathrm{E}+0$ & $1.0 \mathrm{E}+0$ & $1.0 \mathrm{E}+0$ \\
\hline ArtifBanks & Bank artificialization & $8.1 E-6$ & $7.0 \mathrm{E}-7$ & $1.9 \mathrm{E}-6$ & $1.4 \mathrm{E}-7$ & $1.1 E-3$ & $1.4 \mathrm{E}-4$ & $1.1 \mathrm{E}-2$ & $1.3 \mathrm{E}-3$ & $1.1 \mathrm{E}-2$ & $5.2 \mathrm{E}-4$ & $3.7 \mathrm{E}-1$ & $1.6 \mathrm{E}-1$ \\
\hline ArtifBuff & Artificial areas in the buffer & $1.4 \mathrm{E}-2$ & $1.3 E-3$ & $8.6 E-4$ & $1.1 \mathrm{E}-5$ & $4.8 \mathrm{E}-2$ & $4.4 \mathrm{E}-3$ & $3.9 \mathrm{E}-3$ & $2.6 \mathrm{E}-6$ & $1.3 \mathrm{E}-1$ & $8.2 \mathrm{E}-3$ & $1.0 \mathrm{E}+0$ & $1.0 \mathrm{E}+0$ \\
\hline ObstDens & Longitudinal density of obstacle & $7.1 \mathrm{E}-3$ & $1.6 \mathrm{E}-3$ & $9.9 \mathrm{E}-4$ & $1.6 \mathrm{E}-5$ & $7.8 E-5$ & $2.8 \mathrm{E}-8$ & $2.3 E-4$ & $3.2 \mathrm{E}-11$ & $1.1 \mathrm{E}-3$ & $2.9 \mathrm{E}-7$ & $1.3 \mathrm{E}-2$ & $1.6 \mathrm{E}-5$ \\
\hline
\end{tabular}
Variables showing $\mathrm{p}<0.05$ for both tests are in bold. 


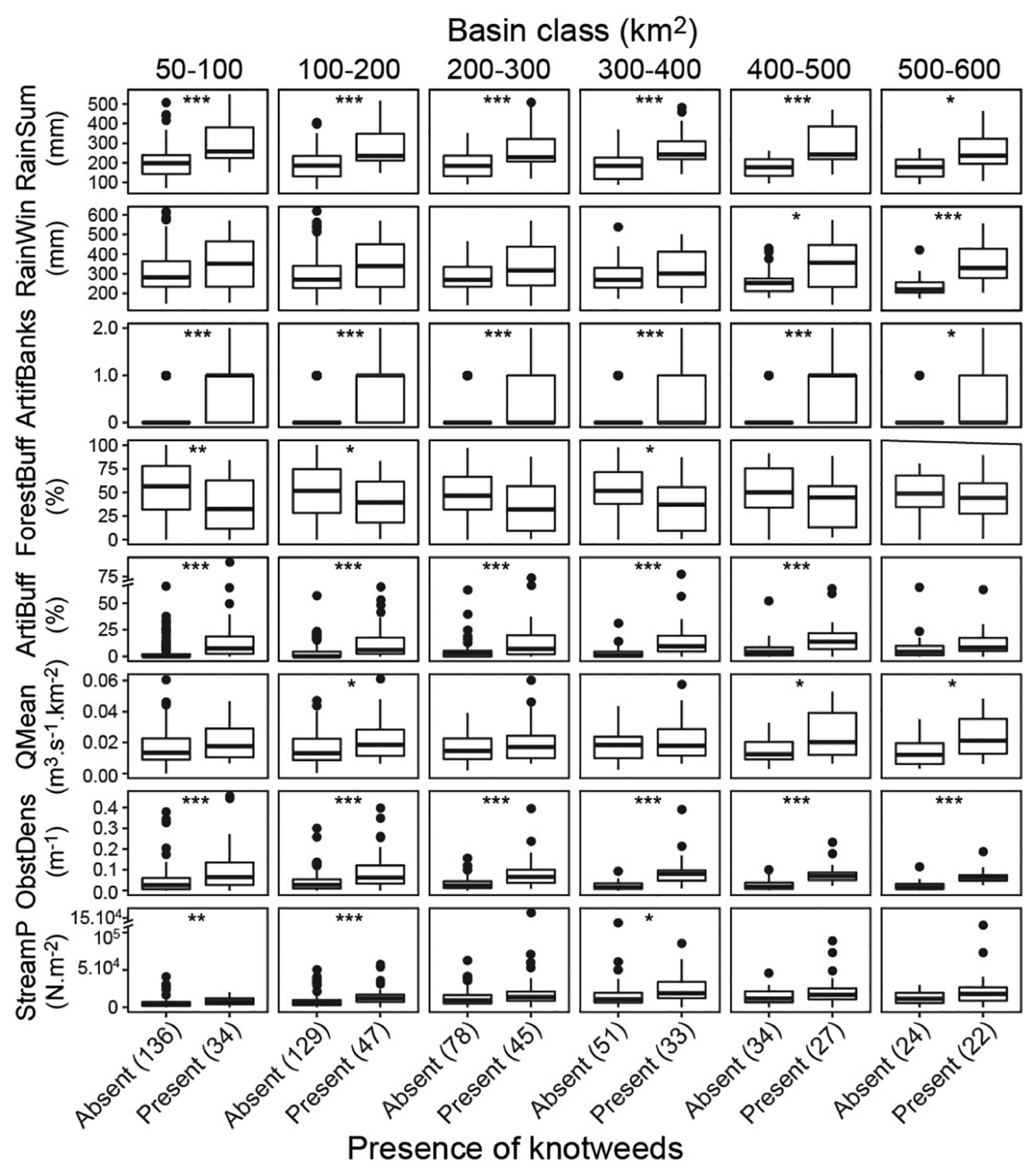

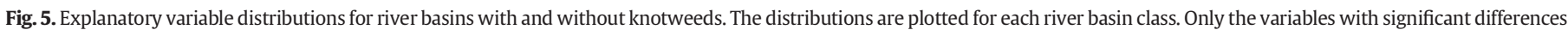
(Wilcoxon test and Khi-2 for ArtifBank) were plotted $\left({ }^{*}=<0.05\right.$; $^{* *}=<0.01$; $^{* * *}=<0.001$ ).

variables in their own watershed. Two variables used in the previous six models studied (ArtifBanks and EroBanks) are ordinal qualitative and difficult to obtain by basin managers automatically with GIS or remote sensing. An operations-oriented model (noted "OpModel") was developed with the following variables: (1) RainSum, i.e., the cumulative summer rainfall; (2) ForestBuff, i.e., the fraction of forested area in a buffer; (3) ArtifBuff, i.e., the fraction of artificialized zone in the buffer; (4) ObstDens, i.e., the longitudinal density of obstacles to the flow; and (5) StreamP, i.e., the specific stream power. OpModel (Eq. (4)) was calibrated with the $300-400 \mathrm{~km}^{2}$ basin class dataset. OpModel is expressed as:

$\log \left(\frac{p}{1-p}\right)=-7.561+0.022$ RainSum -0.019 ForestBuff

+0.103 ArtifBuff +54.8 ObstDens $+3.7 E^{-6}$ StreamP (4)
OpModel shows relatively low FP rates $(<20 \%)$ and high accuracy ( $>80 \%$ ) for the different size classes of validation basins (Fig. A1). The stream power is relevant for this model and presents a positive link with knotweed density.

\section{Discussion}

\subsection{Invasion processes at stake at river basin scales}

The influence of explanatory variables in explaining knotweed occurrence is highly dependent on spatial scale. At the HER scale, a south-to-north gradient was identified, but no variable could explain the spatial variability of knotweed. Only undertaking analysis at the river basin scale helps to explain the variability of knotweed occurrence.

Eleven variables significantly contributed to explaining the variability in river basin scales in the range of $50-600 \mathrm{~km}^{2}$ (summarized in 
Table 4

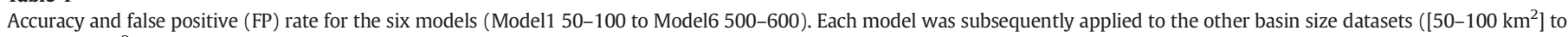
[500-600 $\left.\mathrm{km}^{2}\right]$ ). The accuracy and the FP for each model applied to the basin dataset are in bold.

\begin{tabular}{|c|c|c|c|c|c|c|c|}
\hline & & \multicolumn{6}{|c|}{ Basin size samples used to test the models $\left(\mathrm{km}^{2}\right)$} \\
\hline & & $50-100$ & $100-200$ & $200-300$ & $300-400$ & $400-500$ & $500-600$ \\
\hline \multirow[t]{6}{*}{ Accuracy (\%) } & Model1 50-100 & 87 & 85 & 75 & 74 & 74 & 72 \\
\hline & Model2 100-200 & 86 & 82 & 76 & 80 & 85 & 72 \\
\hline & Model3 200-300 & 81 & 79 & 80 & 87 & 85 & 72 \\
\hline & Model4 300-400 & 79 & 75 & 80 & 90 & 85 & 72 \\
\hline & Model5 400-500 & 68 & 74 & 80 & 88 & 88 & 89 \\
\hline & Model6 500-600 & 61 & 67 & 74 & 84 & 87 & 87 \\
\hline \multirow[t]{6}{*}{ False positive rate (FP) } & Model1 50-100 & 47 & 54 & 65 & 67 & 60 & 60 \\
\hline & Model2 100-200 & 39 & 41 & 52 & 40 & 30 & 55 \\
\hline & Model3 200-300 & 18 & 28 & 31 & 25 & 23 & 46 \\
\hline & Model4 300-400 & 12 & 24 & 23 & 13 & 19 & 19 \\
\hline & Model5 400-500 & 15 & 20 & 18 & 12 & 19 & 19 \\
\hline & Model6 500-600 & 18 & 22 & 18 & 9 & 12 & 14 \\
\hline
\end{tabular}

Table 5). Each of the variables identified can be associated with at least one stage of knotweed transfer in the river network: i) plant introduction, i.e., "how do knotweeds enter into the hydrosystem?"; ii) plant transfer, i.e., "how are stems, rhizome fragments, and achenes remobilized from riverbanks and transferred into the hydrosystem?"; and iii) plant fate, i.e., "which factors provide a hosting environment to knotweeds?" The following discussion aims to associate each explanatory variable to each stage of knotweed transfer (summarized in Table 5). Each explanatory variable shows either a positive (in red in Table 5) or a negative (in green) influence on knotweed occurrence according to both LRT and WT (Table 3). Scale-dependence analysis was led with WT/LRT variations with catchment size (Table 3 ) and is discussed in more detail in the following sections.

\subsection{The main influence of the climate and its scale dependence}

Rainfalls and mean interannual discharge (RainWin, RainSum, Qmean) affect knotweed presence in the same sense, but their respective influence on knotweed density varies with increasing river basin size (Table 3). Our study has clearly illustrated a significant and low presence of knotweed when summer rainfall is lower than $220 \mathrm{~mm} /$ yr. This observation is consistent with knowledge about the conditions

Table 5

Summary of the variables considered in the discussion as key factors at the main stages of the transfer of knotweed: i) introduction; ii) dispersal; and iii) plant installation and growth. Variables with positive trends are in red; negative influences are in green. The scales at which these explanatory variables are the most relevant are also indicated (Table 3).

\begin{tabular}{|c|c|c|c|c|}
\hline \multirow{2}{*}{$\begin{array}{l}\text { Environmental, } \\
\text { human factors }\end{array}$} & \multirow[t]{2}{*}{ Explanatory variable } & \multicolumn{3}{|c|}{ Main stages of knotweeds transfer } \\
\hline & & $\begin{array}{l}\text { Plant } \\
\text { introduction }\end{array}$ & $\begin{array}{l}\text { Plant } \\
\text { dispersal }\end{array}$ & $\begin{array}{l}\text { Plant } \\
\text { installation } \\
\text { and growth }\end{array}$ \\
\hline \multirow[t]{2}{*}{ Human activities } & $\begin{array}{l}\text { Obstacle density (ObstDens) } \\
\text { Artificial basin (ArtiBas) }\end{array}$ & Every scale & & Every scale \\
\hline & $\begin{array}{l}\text { Artificial corridor (ArtiBuff) } \\
\text { Artificial banks (ArtiBanks) }\end{array}$ & $<500 \mathrm{~km}^{2}$ & & $<500 \mathrm{~km}^{2}$ \\
\hline Hydrogeomorpholo & Stream power (StreamP) & & $100-200 \mathrm{~km}^{2}$ & $100-200 \mathrm{~km}^{2}$ \\
\hline gy & Bank erosion (ErosBank) & & $300-500 \mathrm{~km}^{2}$ & $300-500 \mathrm{~km}^{2}$ \\
\hline Land-cover & $\begin{array}{l}\text { Riparian forest surfaces in } \\
\text { buffer (ForesBuff) }\end{array}$ & & & $<400 \mathrm{~km}^{2}$ \\
\hline Soils & Loose soils (Lithloose) & & & $200-300 \mathrm{~km}^{2}$ \\
\hline \multirow[t]{2}{*}{ Climate } & $\begin{array}{l}\text { Rainfall in summer in the basin } \\
\text { (RainSum) }\end{array}$ & & & $<500 \mathrm{~km}^{2}$ \\
\hline & $\begin{array}{l}\text { Rainfall in winter in the basin } \\
\text { (RainWin) }\end{array}$ & & & $>400 \mathrm{~km}^{2}$ \\
\hline Hydrology & $\begin{array}{l}\text { Average interannual discharge } \\
\text { (QMean) }\end{array}$ & & & $400-500 \mathrm{~km}^{2}$ \\
\hline
\end{tabular}


required by knotweeds: knotweeds need water and soil moisture to develop, hence their large presence along permanent rivers (Barney, 2006). Summer rainfalls are relevant at every scale, but their influence decreases in larger basins ( $>500 \mathrm{~km}^{2}$; Table 3 ). In contrast, the influence of winter rainfall increases with a larger catchment area ( $>400 \mathrm{~km}^{2} ; p$-values for the LR test decrease from $10^{-1}$ to $10^{-4}$, Table 3). Such trends can be interpreted as showing that knotweed occurrence is greatly dependent upon water availability and thus upon the different hydrological processes involved at these different scales. For small basins, water availability and soil moisture are mainly controlled by rainfall during the vegetative period (thin soils, steep slopes). The largest basins are, however, associated with gentle slopes and deep soils; for these catchments, the groundwater contribution to the river flow generally increases with the drainage area and mainly depends on winter rainfall (or snowmelt in mountainous regions; $>250 \mathrm{~mm} /$ $\mathrm{yr}$ ). This interpretation may highlight a relationship between hydrological processes and knotweed occurrence in the basins.

\subsection{River disturbances by floods: the complex role of hydrogeomorphological forces}

Flood parameters, i.e., bankfull discharge (QBankfull) or the exceedance probability flow (e.g., Q05\%), show nonlinear relationships with knotweed density (Fig. 4). Floods were identified as being connected with increased knotweed density (density range $0-50 \%$; KruskalWallis post hoc test with $p<0.05$ ). Floods may be an important agent in removing propagules and spreading them into the hydrographic network (observed for other invasive plants by Truscott et al. (2006) and Pattison et al. (2017)). However, the highest knotweed densities (i.e., 50-100\%) are not associated with the highest flood peak discharge but rather with moderate peak discharges (Fig. 4, QBankfull and Q05\%). High flood peaks could thus be a limiting factor for knotweed.

Hydrogeomorphic variables are also identified as significant factors for plant dispersal, installation, and growth. Bank erosion is positively related to knotweed density, so river basins with eroded stream banks may provide favourable conditions of aerial stem or rhizome fragment transport by floods. Eroded banks (without riparian forests) may also be more conducive to the establishment and development of achenes and vegetative propagules. Specific stream power, a classical geomorphic parameter, increases the probability of knotweed occurrence in river basins (Kruskal-Wallis post hoc test with $\mathrm{p}<0.05$; Fig. 4). Fluvial dynamics could enhance bank erosion with a higher dissemination of knotweed vegetative propagules in the river network (Colleran and Goodall, 2014), and even moderate floods could favour knotweed dispersal and development (Table 5).

\subsection{River vegetation and lithological influences on knotweed occurrence}

Our results also demonstrate that the denser and more continuous the riparian vegetation is, the less knotweed is present in the river basin (Fig. 4, ForestBuff). This result confirms the important roles played by light availability in mature forests (e.g., Bímová et al., 2004; Schnitzler, 1997) and competition between knotweeds and other riparian species (Dommanget et al., 2019). All the variables describing riparian vegetation show the same pattern. For instance, the explanatory variable ForestBuff (Table 5), which we used in the final model (Model300-400 at Eq. (3), and OpModel at Eq. (4)), indicates that trees or shrubs covering the river corridor limit the presence of knotweed, especially in basin areas of $<200 \mathrm{~km}^{2}$. This result is consistent with field observations and with research literature identifying knotweed as a pioneering heliophile that would better grow in open spaces rather than in the shade of dense trees or shrubs (e.g., Dommanget et al., 2019).

The lithology (for both basin and river buffer scales) emerged from this basin analysis at only one basin scale $\left(200-300 \mathrm{~km}^{2}\right)$. This result illustrates that geology and lithology may have little influence on knotweed spreads at the basin scale, confirming that knotweeds are extremely adaptable and tolerant to a large range of lithological conditions.

\subsection{The role of human activities and the legacy of river infrastructure}

All the variables characterizing human-induced pressure, i.e., the artificialization of river banks (ArtifBank, ObstDens), the river corridor (ArtifBuff), and the river basin (ArtifBasin, PopBasin), suggest the same positive trends regarding knotweed density (Table 5). In other words, the more that an environment is subjected to anthropogenic pressures, the higher the probability is of introducing and dispersing knotweeds in the river dendritic network. Knotweed development close to the transport networks (e.g., roads, bridges, railways) can cause severe road safety problems (Cottet et al., 2020). The management of knotweeds with no care at the intersections between the transport and river networks (represented in the model by ArtifBuff) may represent an important source of propagules in the river system. Machinery used for river works (e.g., earthworks, vehicle movement, hydraulic infrastructure management) could also induce stem fragment spreading and river input. Knotweed development may be facilitated because of a lower density of vegetation cover in these artificial areas (less competition with other species). The different practices used in riparian vegetation management for flood mitigation could also explain these results. River managers are now fully informed about the threat that knotweed poses to the environment. Alien plants tend to be conscientiously factored in riparian vegetation management plans with specific recommendations about removing stems, rhizomes, and seeds from sites and disposing of them safely. However, local field practices sometimes do not follow or are simply unaware of these recommendations. Cutting down riparian forests, clearing riverbanks, and even river restoration projects undertaken without attention to these recommendations can produce a significant volume of fragments from stems and rhizomes. If these fragments are placed on riverbanks without due caution, floods can easily transport them and spread knotweed further downstream.

The density of obstacles ObstDens was identified in this study as the main anthropogenic factor explaining knotweed density (Table 3, Figs. 4 and 5) and remains influential at every spatial scale considered (Wilcoxon $p<0.001$ Fig. 5; WT and LRT at Table 3). Most engineering works (e.g., weirs, river embankments) in France are legacy river structures (e.g., mills, dikes, dams). They are the traces of large-scale historical human activities that have taken place in small catchments for centuries. Knotweed was introduced into France at the beginning of the nineteenth century and spread all over the country as an ornamental plant in private gardens and designed public spaces. Therefore, the importance of the ObstDens parameter could be attributed to the concomitance of these important human activities and the introduction of knotweed in Europe. It must be noted that, similarly, woody debris jams accumulated in the river after floods or by beavers could play the same role as these human infrastructures. Moreover, weirs, dikes and river embankments identified by the ObstDens factor could have created a host environment that is favourable to the establishment and development of knotweed on riverbanks. By limiting riparian vegetation cover, for instance, artificial riverbanks can reduce competition with other plants (we refer to previous results with the variable ForestBuff) and can support the installation of vegetative propagules or achenes deposited during floods, creating shelters for seedling development (Schneider and Sharitz, 1988; Riis and Sand-Jensen, 2006; Gurnell, 2007). In the same vein, weirs may constitute impassable structures for floating achenes and propagules transported during low-flow conditions or frequent and low-intensity floods. The longitudinal river connectivity could thus play an important role in knotweed dispersal, as it does for both sediment and other vegetative particles (Merritt and Wohl, 2006; Gurnell, 2007). Moreover, transversal obstacles create a moisture environment favourable to the establishment of propagules, such as weirs and mill ponds (i.e., bodies of water used as reservoirs for water-powered mills), 
increase the water table locally, and, more generally, enhance the availability of water and nutrients. This historical human pressure could have created hotspots for the preferential development of knotweed. A final, but by no means least significant, reason that might explain the significance of ObsDens in our analysis relates to the daily management of river infrastructures. Local management practices expend substantial effort to maintain or remove dikes, dams, and river obstacles to mitigate the effects of flooding and for river restoration. However, despite local water authorities' heightened awareness of invasive plants and the priority given to managing such vegetation in river basins, the negative representations of knotweeds (Rouifed and Cottet, 2019) and these river works could have accelerated the dispersal of knotweed over decades.

\section{Conclusions and implications for river management}

In this paper, a linear generalized model was developed at the basin scale according to statistical criteria (variance explained, no redundancy of variables), biological criteria (biological relevance of the variables selected), and operational criteria (ease and lower cost to measure explanatory variables on a watershed).

Once it has been validated in other contexts, the model could provide an operational tool to help river managers define the invasibility or the level of sensitivity of their basins to knotweed invasion on stream orders higher than 3. Given that environmental monitoring is very costly-or simply impossible in the case of large river basins-it should also guide river managers in identifying the subcatchments where more field surveys and greater efforts might be needed (Dommanget et al., 2019). These results should help river managers better take into account the biogeographic characteristics of their river in the definition of river basin management plans. Specific attention should be paid to the management of vegetation on dikes, dams, and weirs, and a better concertation between road/railway managers and river managers is now required.

Last, this model could be used to predict future trends of knotweed invasions. For example, since rainfall is an important factor identified in our study, this model should help in anticipating the influence of climate change on the regional variability of knotweed invasibility in the decades to come. Evaluating the influence of river management planning, such as removing river obstacles as part of river restoration projects aimed at producing ecological continuity, is more delicate, if not impossible. Indeed, in this last example, structural river obstacles both serve as sources of propagules and achenes and influence the transfer of knotweed further downstream. Efforts to remove river obstacles, and hydromorphological restoration projects more generally, therefore require a great deal of oversight on the part of river managers: first, during the river works so as not to introduce propagules into the river flow and, subsequently, to avoid generating new environmental conditions that will be more favourable to invasive plant species (e.g., Duarte et al., 2020).

This study demonstrates that scientists as well as policymakers should further replace the notion of single drivers with a more integrated framework to better understand the multiple forces driving the introduction, transfer and fate of knotweed along rivers. The variability of biogeographical contexts has to be taken into account in management plans, as the success of knotweeds significantly depends on their environment. Our research highlights the strong influences of several biophysical factors and (past and present) anthropogenic activities but without in-depth consideration of the social processes and feedback loops. The representations of knotweeds and their influences on the perceptions and discourses of policy makers, local stakeholders and scientists should be considered in future studies. Indeed, human-knotweed relations lead to a multitude of attitudes and practices that in turn influence knotweed success. These relations include past strategies of invasive plant mitigation as well as present and daily vegetation management of hydraulic structures, riverbanks, river restoration works and transport networks (roads and rails). Further research is now needed to better understand the tangled biophysical and social feedback loops controlling knotweed occurrence in river corridors. This result can only be achieved by adding social complexity to ecological complexity (Head, 2017).

Supplementary data to this article can be found online at https://doi. org/10.1016/j.scitotenv.2020.142995.

\section{CRediT authorship contribution statement}

O. Navratil: Conceptualization, Formal analysis, Funding acquisition, Methodology, Project administration, Supervision, Validation, Writing original draft. N. Brekenfeld: Data curation, Formal analysis, Methodology, Software, Visualization, Writing - review \& editing. S. Puijalon: Conceptualization, Data curation, Formal analysis, Funding acquisition, Methodology, Visualization, Writing - original draft. M. Sabastia: Formal analysis. M. Boyer: Data curation, Formal analysis, Writing - review \& editing. H. Pella: Formal analysis, Writing - review \& editing. J. Lejot: Formal analysis, Visualization, Writing - review \& editing. F. Piola: Conceptualization, Funding acquisition, Methodology, Project administration, Supervision, Writing - original draft.

\section{Declaration of competing interest}

The authors declare that they have no known competing financial interests or personal relationships that could have appeared to influence the work reported in this paper.

\section{Acknowledgements}

This work was funded by the Zone Atelier Bassin du Rhône (ZABR) and the RMC Water Agency. This work is part of a research project conducted on the Saône-Rhône basin (2014-2017) entitled "Multi-scale analysis of environmental filters limiting the invasibility of stream banks by knotweeds".

\section{Data availability statement}

The data that support the findings of this study are available from the corresponding author upon reasonable request.

\section{References}

Alexander, S., Nelson, C.R., Aronson, J., Lamb, D., Cliquet, A., Erwin, K.L., Hobbs, R.J., 2011. Opportunities and challenges for ecological restoration within REDD+. Restor. Ecol. 19, 683-689.

Bailey, J.P., Conolly, A.P., 1985. Chromosome numbers of some alien Reynoutria species in the British Isles. Watsonia 15, 270-271.

Bailey, J., Bímová, K., Mandák, B., 2009. Asexual spread versus sexual reproduction and evolution in Japanese knotweed s.l. sets the stage for the "battle of the clones". Biol. Invasions 11 (5), 1189-1203.

Barney, J.N., 2006. North American history of two invasive plant species: phytogeographic distribution, dispersal vectors, and multiple introductions. Biol. Invasions 8, 703-717.

Bendix, J., Hupp, C.R., 2000. Hydrological and geomorphological impacts on riparian plant communities. Hydrol. Process. 14, 2977-2990.

Bendix J., and Stella J.C. Riparian Vegetation and the Fluvial Environment: A Biogeographic Perspective. In: John F. Shroder (Editor-in-chief), Butler, D.R., and Hupp, C.R. (Volume Editors). Treatise on Geomorphology, Vol 12, Ecogeomorphology, San Diego: Academic Press; 2013. p. 53-74.

Bímová, K., Mandák, B., Kašparová, I., 2004. How does Reynoutria invasion fit the theories of invasibility. J. Veg. Sci. 15 (4), 495-504.

Boedeltje, G.E.R., Bakker, J.P., ter Heerdt, G.N., 2003. Potential role of propagule banks in the development of aquatic vegetation in backwaters along navigation canals. Aquat. Bot. 77 (1), 53-69.

Boedeltje, G.E.R., Bakker, J.P., Ten Brinke, A., Van Groenendael, J.M., Soesbergen, M., 2004. Dispersal phenology of hydrochorous plants in relation to discharge, seed release time and buoyancy of seeds: the flood pulse concept supported. J. Ecol. 92 (5), $786-796$.

Boyer, M., 2002. Cartographie des renouées du Japon sur le réseau hydrographique du bassin Rhône Méditerranée et Corse (hors Saône-Doubs). J. Tech. Natl. Besançon 9 (19 et 20 juin 2002 (in french)).

Buhk, C., Thielsch, A., 2015. Hybridisation boosts the invasion of an alien species complex: insights into future invasiveness. Perspect. Plant Ecol. Syst. 17, 274-283. 
Catford, J.A., Jansson, R., 2014. Drowned, buried and carried away: effects of plant traits on the distribution of native and alien species in riparian ecosystems. New Phytol. 204, 19-36. https://doi.org/10.1111/nph.12951.

Chandesris, A., Mengin, N., Malavoi, J.R., Wasson, J.G., Souchon, Y., 2008. SYRAH-CE: a relational, multi-scale system for auditing the hydro-morphology of running waters: diagnostic tool to help the WFD implementation in France. 4th International Conference on River Restoration, Venice, ITA (16-21 June 2008. 4 p).

Chave, J., 2013. The problem of pattern and scale in ecology: what have we learned in 20 years? Ecol. Lett. 16, 4-16. https://doi.org/10.1111/ele.12048.

Colleran, B.P., Goodall, K.E., 2014. In situ growth and rapid response management of flood-dispersed Japanese knotweed (Fallopia japonica). Invasive Plant Sci. Manag. 7, 84-92.

Cottet, M., Rivière-Honegger, A., Evette, A., Piola, F., Rouifed, S., Dommanget, F., Vaudor, L., Valy, J., 2018. Representations and management practices of Asian knotweeds: do they integrate long-term dynamics of ecosystems ? Géocarrefour https://doi.org/ 10.4000/geocarrefour.10451.

Cottet, M., Rivière-Honegger, A., Vaudor, L., Colombain, L., Dommanget, F., Evette, A., 2020. The end of a myth: solving the knotweeds invasion "problem". Anthropocene 30. https://doi.org/10.1016/j.ancene.2020.100240.

Cousens, R., Dytham, C., Law, R., 2008. Dispersal in plants. A Population Perspective. USA. Oxford University Press, New York, N.Y.

D'Antonio, C.M., Dudley, T.L., Mack, M.C., 1999. Disturbance and biological invasions:D irect effects and feedbacks. In: Walker, L. (Ed.), Ecosystemosf Dkturbed Ground. Elsevier, Oxford, U.K., pp. 4I3-452.

Davis, M.A., Grime, J.P., Thompson, K., 2000. Fluctuating resources in plant communities: a general theory of invasibility. J. Ecol. 88, 528-534.

Dommanget, F., Evette, A., Breton, V., Daumergue, N., Forestier, O., Poupart, P., Martin, F.M., Navas, M.L., 2019. Fast-growing willows significantly reduce invasive knotweed spread. J. Environ. Manag. 231, 1-9.

Duarte, L.N., Pinto Gomes, C., Marchante, H., Marchante, E., 2020. Integrating knowledge of ecological succession into invasive alien plant management: a case study from Portugal. Appl. Veg. Sci. https://doi.org/10.1111/avsc.12488 Accepted Author Manuscript.

Engler, J., Abt, K., Buhk, C., 2011. Seed characteristics and germination limitations in the highly invasive Fallopia japonica s.l. (Polygonaceae). Ecol. Res. 26, 555-562.

Frissell, C.A., Liss, W.J., Warren, C.E., Hurley, M.D., 1986. A hierarchical framework for stream habitat classification: viewing streams in a watershed context. Environ. Manag. 10 (2), 199-214.

Funkenberg, T.I.M., Roderus, D., Buhk, C., 2012. Effects of climatic factors on Fallopia japonica sl seedling establishment: evidence from laboratory experiments. Plant Species Biol. 27 (3), 218-225.

Gurnell, A.M., 2007. Analogies between mineral sediment and vegetative particle dynamics in fluvial systems. Geomorphology $89(1,2), 9-22$.

Head, L., 2017. The social dimensions of invasive plants. Nat. Plants 3, 17075. https://doiorg.inee.bib.cnrs.fr/10.1038/nplants.2017.75.

Hewitt, J.E., Thrush, S.F., Lundquist, C., 2017. Scale-dependence in ecological systems. eLS. John Wiley \& Sons Ltd, Chichester https://doi.org/10.1002/9780470015902. a0021903.pub2.

Lamberti-Raverot, B., Piola, F., Thiébaut, M., Guillard, L., Vallier, F., Puijalon, S., 2017. Water dispersal of the invasive complex Fallopia: the role of achene morphology. Flora 167, 150-157.

Lamberti-Raverot, B., Piola, F., Vallier, F., Gardette, V., Puijalon, S., 2019. Achene traits involved in the water dispersal of the invasive Fallopia $\times$ bohemica complex: variability and dispersal strategies. Flora 251, 88-94.

Lavoie, C., 2017. The impact of invasive knotweed species (Reynoutria spp.) on the environment: review and research perspectives. Biol. Invasions 19, 2319-2337. https:// doi-org.inee.bib.cnrs.fr/10.1007/s10530-017-1444-y.

Lavoie, C., 2019. Les impacts des renouées asiatiques sur l'environnement et les infrastructures. Rev. Sci. Eaux Territ. Renouées Envahissantes Connaissances Gestions Perspect. numéro 27, 14-19. https://doi.org/10.14758/SET-REVUE.2019.1.03.
Levin, S.A., 1992. The problem of pattern and scale in ecology. Ecology 73, 1943-1967. Lonsdale, W.M., 1999. Global pattern of plant invasion and the concept of invasibility. Ecology 80, 1522-1536.

Lowe, S., Browne, M., Boudjelas, S., De Poorter, M., 2000. 100 of the World's Worst Invasive Alien Species: A Selection from the Global Invasive Species Database. Invasive Species Specialist Group, Auckland, New Zealand.

Mahoney, J.M., Rood, S.B., 1998. Streamflow requirements for cottonwood seedling recruitment-an integrative model. Wetlands 18 (4), 634-645.

Mandák, B., Pyšek, P., Bímová, K., 2004. History of the invasion and distribution of Reynoutria taxa in the Czech Republic: a hybrid spreading faster than its parents. Preslia 76, 15-64.

Merritt, D.M., Wohl, E., 2002. Processes governing hydrochory along rivers: hydraulics, hydrology, and dispersal phenology. Ecol. Appl. 12 (4), 1071-1087.

Merritt, D.M., Wohl, E.E., 2006. Plant dispersal along rivers fragmented by dams. River Res. Applic. 22, 1-26. https://doi.org/10.1002/rra.890.

Pattison, Z., Minderman, J., Boon, P.J., Willby, N., 2017. Twenty years of change in riverside vegetation: what role have invasive alien plants played? Appl. Veg. Sci. 20, 422-434. https://doi.org/10.1111/avsc.12297.

Pella, H., Lejot, J., Lamouroux, N., Snelder, T., 2012. Le réseau hydrographique théorique (RHT) français et ses attributs environnementaux. Géomorphologie. Groupe français de géomorphologie 2012/3 n³. (126 p).

R Core Team, 2017. R: A Language and Environment for Statistical Computing. R Foundation for Statistical Computing, Vienna, Austria.

Rejmanek, M., 1989. Invasibility of plant communities. In: Drake, J., Mooney, H., di Castri, F., et al. (Eds.), Bio-logical Invasions. A Global Perspective. John Wiley and Sons, Chichester, pp. 215-255.

Riis, T., Sand-Jensen, K.A.J., 2006. Dispersal of plant fragments in small streams. Freshw. Biol. 51 (2), 274-286.

Rouifed, S., Cottet, M., 2019. Gestion des renouées: peut-on ou doit-on changer de perspectives? Rev. Sci. Eaux Territ. Renouées Envahissantes Connaissances Gestions Perspect. 27, 114-117.

Rouifed, S., Puijalon, S., Viricel, M.R., Piola, F., 2011. Achene buoyancy and germinability of the terrestrial invasive Fallopia $\times$ bohemica in aquatic environment: a new vector of dispersion? Ecoscience 18 (1), 79-84.

Rouifed, S., Piola, F., Spiegelberger, T., 2014. Invasion by Fallopia spp. in a French upland region is related to anthropogenic disturbances. Basic Appl. Ecol. 15, 435-444.

Sauquet, E., Catalogne, C., 2012. Cartographie des débits de référence - Interpolation des caractéristiques d'étiage. Final report, ONEMA 60 pp.

Schneider, R.L., Sharitz, R.R., 1988. Hydrochory and regeneration in a bald cypress-water tupelo swamp forest. Ecology 69 (4), 1055-1063.

Schnitzler, A., 1997. River dynamics as a forest process: interaction between fluvial systems and alluvial forests in large European river plains. Bot. Rev. 63, 40-64.

Steinbauer, M.J., Schweiger, A.H., Irl, S.D.H., 2016. Biogeography, patterns in. In: Kliman, R.M. (Ed.), Encyclopedia of Evolutionary Biology. vol. 1. Academic Press, Oxford, pp. 221-230.

Tickner, D.P., Angold, P.G., Gurnell, A.M., Mountford, J.O., 2001. Riparian plant invasions: hydrogeomorphological control and ecological impacts. Progress Phys. Geogr. Earth Environ. 25 (1), 22-52. https://doi.org/10.1177/030913330102500102.

Tilman, D., 1997. Community invasibility, recruitment limitation, and grassland biodiversity. Ecology 78, 81-92.

Truscott, A.M., Soulsby, C., Palmer, S.C.F., Newell, L., Hulme, P.E., 2006. The dispersal characteristics of the invasive plant Mimulus guttatus and the ecological significance of increased occurrence of high-flow events. J. Ecol. 94 (6), 1080-1091.

Wasson, J.G., Chandesris, A., Pella, H., Blanc, L., 2002. Les hydro-écorégions de France métropolitaine. Approche régionale de la typologie des eaux courantes et éléments pour la définition des peuplements de référence d'invertébrés. Ministère de l'Écologie et du Développement durable, Cemagref BEA/LHO (190 p).

Wohl, et al., 2019. Connectivity as an emergent property of geomorphic systems. Earth Surf. Process. Landf. 44, 4-26. https://doi.org/10.1002/esp.4434. 